\title{
Glass eel monitoring in the Netherlands
}

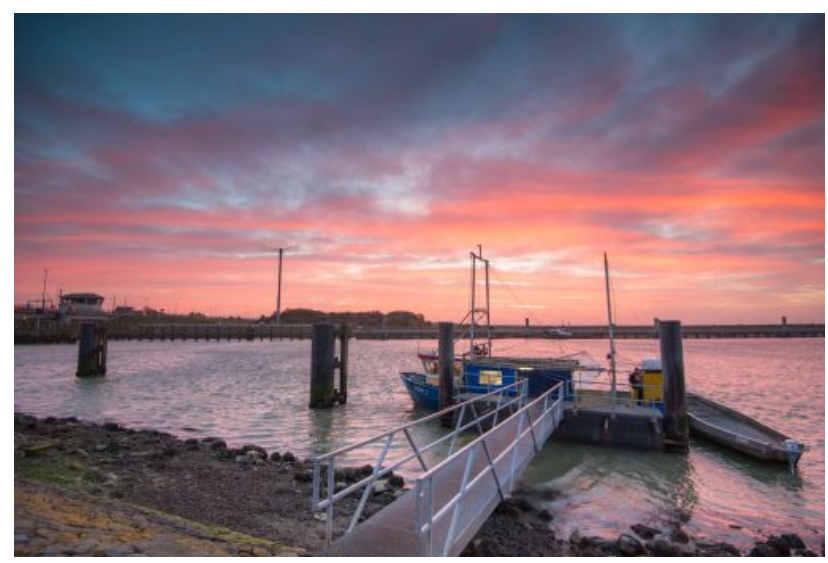

Author(s):

A.B. Griffioen, P. de Vries, R.H. Twijnstra and M. de Graaf

Publication date: 13 February 2013

This research project was carried out by Wageningen Marine Research at the request of and with funding from the Ministry of Economic Affairs for the purposes of Policy Support Research Theme 'WOT-05 Visserij' (WOT-05-001-017).

Wageningen Marine Research

IJ muiden, February 2017

Wageningen Marine Research report C010/17 
Griffioen, A.B. P. de Vries, R.H. Twijnstra and M. de Graaf 2016. Glass eel monitoring in the Netherlands. Wageningen, IMARES Wageningen UR (University \& Research centre), I MARES report C010/17. $41 \mathrm{pp}$.

Client: Ministerie van Economische Zaken

Attn.: M. Snijdelaar

Bezuidenhoutseweg 73

2594 AC Den Haag

WOT-05-001-017-I MARES-10

Wageningen Marine Research is ISO 9001:2008 certified.

Dit rapport is gratis te downloaden van: https://doi.org/10.18174/408032

Wageningen Marine Research verstrekt geen gedrukte exemplaren van rapporten.

(C) 2016 Wageningen Marine Research Wageningen UR

Wageningen Marine Research The Management of Wageningen Marine Research is not responsible for resulting institute of Stichting Wageningen damage, as well as for damage resulting from the application of results or Research is registered in the Dutch research obtained by Wageningen Marine Research, its clients or any claims traderecord nr. 09098104, BTW nr. NL 806511618 related to the application of information found within its research. This report has been made on the request of the client and is wholly the client's property. This report may not be reproduced and/or published partially or in its entirety without the express written consent of the client. 


\section{Contents}

$\begin{array}{lr}\text { Summary } & 4\end{array}$

$1 \quad$ Introduction $\quad 5$

$2 \quad$ Glass eel in the Netherlands $\quad 6$

2.1 The current state of European (glass) eel in the Netherlands 6

$\begin{array}{lll}2.2 & \text { Biology and behaviour of glass eel } & 7\end{array}$

$\begin{array}{ll}2.3 \text { Monitoring of glass eel abundance } & 9\end{array}$

$3 \quad$ Glass eel monitoring projects along the Dutch Coast $\quad 10$

$4 \quad$ Exploration of a national glass eel trend analysis $\quad 19$

4.1 Data availability national glass eel trend 19

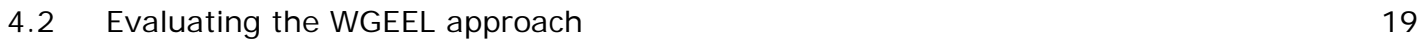

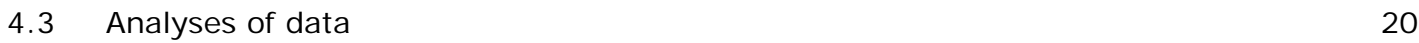

$\begin{array}{lll}4.4 & \text { National trend of glass eel } & 20\end{array}$

$\begin{array}{ll}4.5 & \text { Discussion, conclusions and recommendations } \\ \end{array}$

$5 \quad$ Relation of glass eel abundance and tidal water levels at tidal gates 24

5.1 Data availability and data processing 24

5.1.1 Glass eel data $\quad 24$

5.1.2 Water level data $\quad 24$

$\begin{array}{lll}5.2 & \text { Relation eel catches and tidal currents } & 26\end{array}$

$\begin{array}{lll}5.3 \text { Conclusion } & 28\end{array}$

6 Discussion: Monitoring glass eel at barriers using lift nets 29

$7 \quad$ Conclusions and recommendations 33

$8 \quad$ Acknowledgements $\quad 35$

9 Quality Assurance $\quad 36$

$\begin{array}{lr}\text { References } & 37\end{array}$

$\begin{array}{lr}\text { J ustification } & 39\end{array}$ 


\section{Summary}

The European eel (Anguilla anguilla L.) is an economical important species in severe decline: landings from and recruitment to the stock have dramatically declined since the mid-1960s and the early 1980s, respectively. To evaluate yearly fluctuations of glass eel abundance along the Dutch coast, Wageningen Marine Research has long-running monitoring programs at different sites in the Netherlands. Comparable to the ICES European eel index, the Netherlands has several monitoring datasets but one overall 'national' index is lacking. This report evaluates the possibility to produce one national eel index that is sensible and takes into account different monitoring projects and locations. In addition, glass eel monitoring data will be analysed in relation to tidal currents to identify behavioural patterns.

In the Netherlands many glass eel monitoring programs have been executed throughout the years and many of them are still ongoing. In general there are five monitoring projects using small $1 \times 1$ liftnets along the Dutch coast or at freshwater barriers: (1) "WOT Wageningen Marine Research", (2) "Ruim baan voor vissen", (3) "collaboration of different parties along the Noordzeekanaal", (4) "Collaboration of different parties of the South West Delta" and (5) "Monitoring Zeeuwse Eilanden". However, many time series are relatively short and exposed to or will be exposed to changes in the local situation, potentially causing difficulties in trend analysis due to a changed ratio between catches and the underlying unknown true numbers that are present. The monitoring program of Wageningen Marine Research is the only program with longer (e.g. >10 years) time series and therefore valuable for historic, year to year, comparison. Clearly, the most thoroughly monitored location is Den Oever with, by far, the most hauls per year. This dataset has several hauls per night throughout the tidal cycle, on consecutive days, throughout the migration period and since 1938.

The first exploration towards calculating one national glass eel index showed that it is highly influenced by the monitoring intensity at Den Oever, since the trend has been weighted by the number of hauls. Therefore, at this stage the national index is a 'noisy version' of the index graph of Den Oever. The other locations introduce noise in the index graph. For future purposes it is therefore recommended to intensify the number of hauls at the other locations. Preferably at locations along the Dutch coast and not in freshwater or brackish systems at secondary barriers.

There is a relation between glass eel abundance and tidal current with relatively more glass eel during high tide at Den Oever. Furthermore, catches are increasing with rising tide and, slowly, decreasing during ebbing tide. On average, during all tidal phases glass eel were caught. But, largest catches can be expected during high tide. When this type of monitoring is used for fish pass evaluation, management measure advice or simply as year to year index, it is important to take into account tidal cycles. An irregular planning of monitoring at tidal gates, in relation to tidal phases could cause biased conclusions. It would be better to take sufficient hauls during different phases of the tidal cycle, or correct for the tidal state during sampling with a statistical model. 


\section{Introduction}

The European eel (Anguilla anguilla L.) is an economical important species in severe decline: landings from and recruitment to the stock have dramatically declined since the mid-1960s and the early 1980s, respectively (Dekker 2004b). In addition, based on 51 time-series, the latest ICES WGEEL report (2015) stated that both the glass eel index and the yellow eel index have fallen compared to the reference period starting at 1960 (ICES 2016). Many factors may contribute to this decline and most that have been suggested are anthropogenic. Important factors that are mentioned are migratory barriers such as dams, hydropower stations, weirs or ship locks, which all may cause high mortality rates, blockage or delay for eel at different life stages, but also fisheries, parasites, pollution and climate change may contribute to this decline (Feunteun 2002, Wirth and Bernatchez 2003, Dekker 2004a, Winter and Jansen 2006, Winter et al. 2006, Jansen et al. 2007, Winter et al. 2007b, Acou et al. 2008, Calles et al. 2010, Pedersen et al. 2012, Winter et al. 2013, Winter et al. 2014, Wolfshaar et al. 2015).

To evaluate yearly fluctuations of glass eel abundance along the Dutch coast, Wageningen Marine Research has long-running monitoring programs at different sites in the Netherlands. The longest lasting monitoring program, located at Den Oever, has started in 1938 and collects a yearly dataset consisting of hundreds of hauls at the discharge sluices using a $1 \times 1 \mathrm{~m}$ liftnet. The data is collected between 22:00 - 05:00 (dark period). Besides this location, other locations along the Dutch coast are sampled using the same methodology, but less intensive.

In addition to the long-running monitoring program of Wageningen Marine Research, many other voluntary programs have been set up to evaluate the densities of small diadromous fish, including glass eel, along the Dutch coast and several freshwater barriers (Wintermans and Jager 2003, Winter et al. 2007a, Werkgroep Monitoring Noordzeekanaal 2014, Projectgroep Samen voor de Aal 2015, Wintermans 2015). Many of these programs are monitored for a few years and give insight in abundance of (small) diadromous fish near barriers. Besides these monitoring programs, many other temporal programs have been executed with different goals such as determining overall abundance, study behaviour, develop or test sampling methodologies etc. (Kruitwagen and Klinge 2007a, b, 2008, Hop and Kampen 2012, Foekema et al. 2014, Griffioen et al. 2014, Ruijter 2014, Schaub et al. 2014, Bergsma 2015, Foekema et al. 2015)

Comparable to the ICES European eel index, the Netherlands has several monitoring datasets but combining these into one overall 'national' index has not been undertaken yet. This report evaluates the possibility to produce one national eel index that is sensible and takes into account different monitoring projects and locations. In addition, glass eel monitoring data will be analysed in relation to tidal currents to identify behavioural patterns and potentially reduce sampling variation due the possibility to correct for environmental factors such as tides. This latter analysis will be executed on the data collected at Den Oever, since this is the only dataset covering multiple years and has a standardized number of hauls per night on consecutive days. In general there are three subjects described in this report:

1. Overview and brief evaluation of glass eel monitoring projects along the Dutch coast

2. Exploration of a national glass eel index based on multiple datasets along the Dutch Coast

3. Analysis of the relation between tidal currents and glass eel monitoring at Den Oever

The aim of this report is to evaluate the glass eel monitoring in the Netherlands, explore the possibility to produce a national glass eel index and to give advice on monitoring glass eel and selecting new locations. 


\section{$2 \quad$ Glass eel in the Netherlands}

\section{$2.1 \quad$ The current state of European (glass) eel in the Netherlands}

Glass eel

The European eel is a catadromous species that (generally) realises most of its growth in freshwater ecosystems. It is one of the most important commercial species of the inland waters. However, since 1980 there has been a dramatic decline of the abundance of glass eel along the Dutch coast, as indicated by data collected at Den Oever (Figure 2-1). At the moment, the current level of the glass eel index is less than $5 \%$ of its former level before 1980. The last 16 years, the index level has a relative stable, but low, level with few glass eel per haul on average, while in the early eighties the average was around 80 eel per hauls and in the sixties this could be above 100 eel per haul. In 2015, the index has dropped to a historic low level of 0.24 glass eel per haul ( $n=480$ hauls in May and April). The causes for this decline are not known and but most probably a combination of different (in) direct anthropogenic factors e.g. fisheries, climate change, loss of habitat, pollution, barriers, etc.

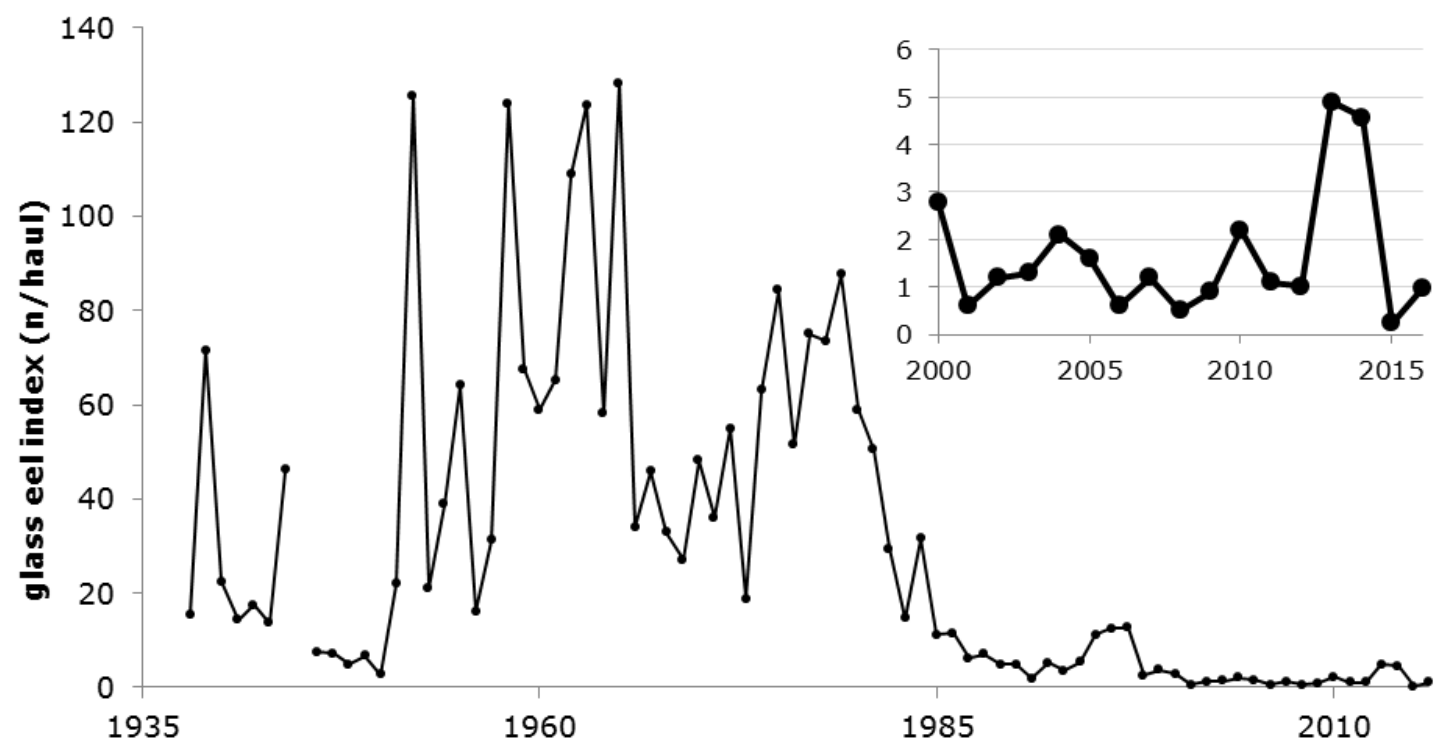

Figure 2-1 Glass eel monitoring data at Den Oever (1938 - 2016). Data represents number of glass eel per haul caught in April and May, calculated for each year separately.

Yellow eel

The abundance ( $\mathrm{n} / \mathrm{ha}$ ) of yellow eel in lake IJsselmeer and Markermeer has decreased since 2000 as indicated by active trawl monitoring (Graaf and Deerenberg 2015). Moreover, in the upstream parts of the large rivers in the Netherlands, the number of eel collapsed, while the average length of the monitored eel increased. This suggest strong decrease in recruitment of young eels in the upper parts of the rivers (Graaf and Deerenberg 2015). Contrary to the upper parts, the lower parts of the rivers do not show a change in average eel length or number of eel since the monitoring started in 1998 (Graaf and Deerenberg 2015). 


\subsection{Biology and behaviour of glass eel}

Spawning occurs in the Sargasso sea (Schmidt 1922, Tesch 1998), whereafter the Leptocephali larvae drift towards the European and North African continent (Figure 2-2). Eventually, glass eel arrive during late winter, early spring up to late spring at the coast and actively swims towards freshwater ecosystems for maturation. Glass eel arrives at the Dutch coast at water temperatures between 3$11^{\circ} \mathrm{C}$ and mostly between $6-9^{\circ} \mathrm{C}$ (van Heusden 1943). At the stage that they enter freshwater habitat, the glass eel change again, actively swimming upstream, darkening as pigmentation develops (Dekker 2002c). The main growing stage is referred to as yellow eel and after a few years they change again and leave the freshwater systems as maturing silver eel for spawning in marine environments. Migration between freshwater and marine water is essential to fulfil their life cycle. However, also in the Wadden Sea, yellow eel catches have been reported (Graaf and Deerenberg 2015). They probably realised their growth in a marine environment. Similar to the glass eel abundance monitoring at Den Oever, these yellow eel catches in the Wadden Sea decreased dramatically after 1980 (van der Meer et al. 2011, Graaf and Deerenberg 2015). It is remarkable that with the strong decline of the freshwater eel population, the population in the Wadden Sea also declined while these marine habitats are freely accessible habitats contrary to the most of the freshwater habitats. This implies that the Wadden Sea may be a sub-optimal habitat and that eel may prefer freshwater ecosystems to complete the main growth phase. A stable or increasing yellow eel population in a marine environment may be an indication that the carrying capacity of the optimal freshwater habitats have been reached. However, this latter hypothesis has not been tested yet.

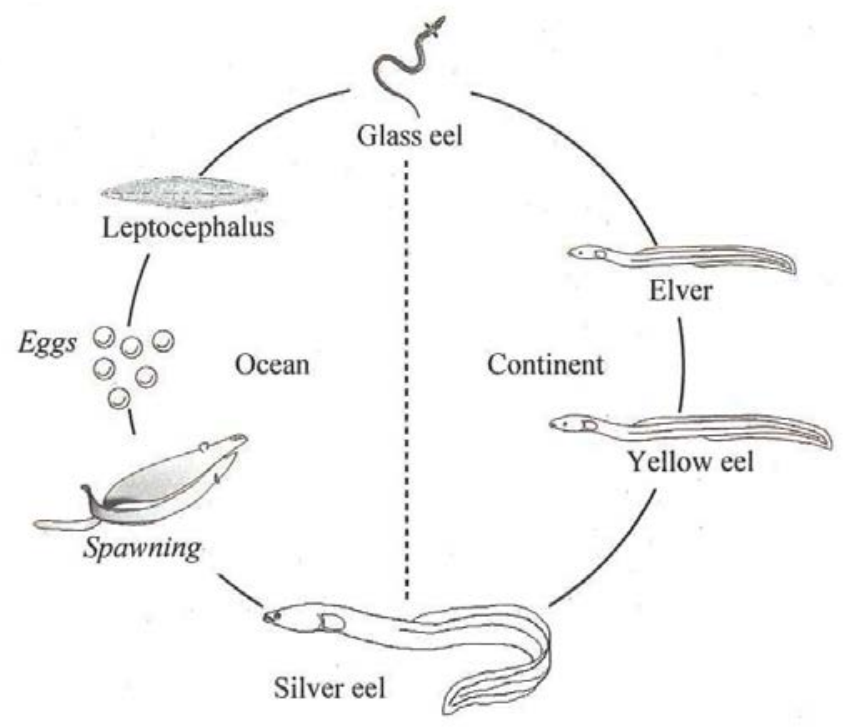

Figure 2-2 Life cycle of the eel. The names of the major life stages have been indicated. Spawning and eggs have never been observed in the wild and are therefore only tentatively included (Dekker 2002c).

Migration issues and migration strategies

Glass eel migration towards freshwater ecosystems is blocked by all kinds of different artificial structures in water systems. Dams, pumping stations and sluices introduce an unnatural situation in estuarine habitats resulting in limited migratory opportunities for migratory fish including glass eel. It may occur that glass eel that accumulate in the vicinity of tidal barriers are exposed to higher predation risks due to a combination of higher densities and longer retention times. To mitigate these adverse effects, many management measures, fish ladders, dam removal or other solutions have been introduced to facilitate fish migration. Although most of the measures in the Netherlands have not or poorly been tested on efficiency (Kroes et al. 2015). 
Lately, a newly designed fish passage has been proposed to be built in the largest dam in the Netherlands (Afsluitdijk), the 'Fish Migration River (FMR)' (Winter et al. 2014). This fish passage is especially designed to restore an estuarine regime with tidal currents freely moving in and out on a small scale. These currents allow glass eel to make use of selective tidal transport and to drift with tidal currents towards the freshwater lake. An extended review on migration strategy is given in Winter et al. (2014).

Pollution

Several environmental contaminants, including PCBs, dioxins, and some pesticides, have been shown to interfere with fat accumulation and energy consumption of European eel (Robinet and Feunteun 2002, Ginneken et al. 2009). Given concentration levels of dioxin-like contaminants and assuming a relatively high sensitivity, it can be expected that larvae from eggs produced by eel from highly contaminated locations in Europe will experience increased mortality as a result of maternally transferred dioxin-like contaminants (Foekema et al. 2016).

Orientation of glass eel

Besides tidal currents, aromatic substances in the water also play a crucial role in the displacement and orientation of glass eel (Creutzberg 1958, 1959, 1961, Dekker and vanWilligen 1997, Dekker 1998a, Dekker and VanWilligen 2000, Kroon et al. 2013). Especially at greater distance from the coast, the role of organic substances originated from the freshwater may play a larger role than factors as salinity gradients. Creutzberg $(1959,1961)$ showed that fresh water attracted glass eel independent to different salinity gradients. Creutzberg (1959, 1961) concluded that organic substances may be responsible for the attraction of glass eel towards the freshwater ecosystems. A more detailed review of glass eel behaviour and aromatic substances is given by Kroon et al. (2013). 


\subsection{Monitoring of glass eel abundance}

Monitoring of glass eel abundance can be done by using different types of equipment and techniques depending on the life stage, location and their swimming activity (Dekker 2002c, Dekker 2002a, b). In the Netherlands measuring glass eel density is done using a $1 \times 1 \mathrm{~m}$ liftnet with a fine mesh size, preferable $1 \times 1 \mathrm{~mm}$. This net is lowered by a rope, just in front of a barrier (sluice, pumping station, etc), until the bottom is reached. After approximately 5 minutes the net is lifted by pulling the rope at a speed of approximately $1 \mathrm{~m}$ per second (Dekker 2002c). Of course, other techniques are possible to monitor the abundance of glass eel. However, using the, easy to handle, liftnet, will produce a standardized dataset which is preferable in producing a year to year index in order to evaluate trends. Wageningen Marine Research has been monitoring glass eel since 1938 producing a glass eel index at Den Oever. Since the nineties also other locations are sampled, but less extensive (Figure 2-3).

\section{glass eel monitoring locations}

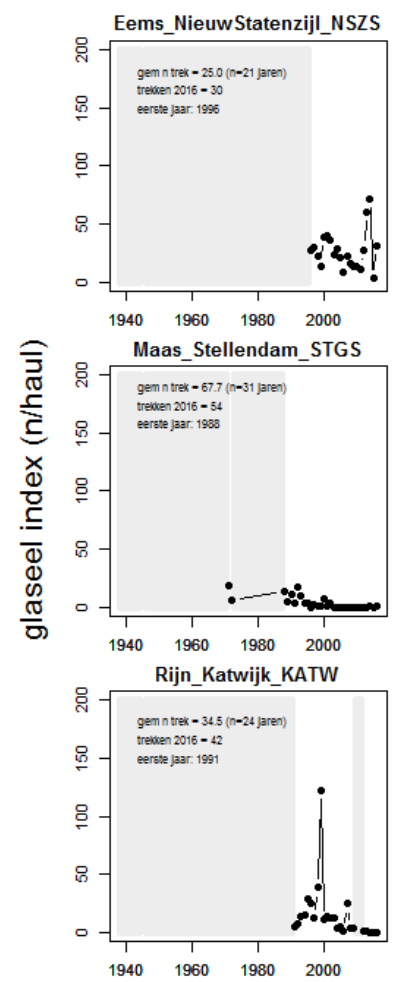

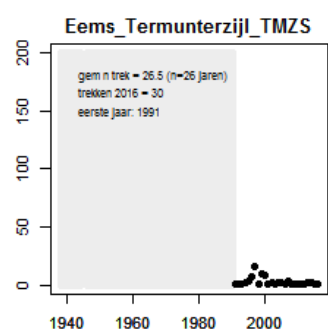
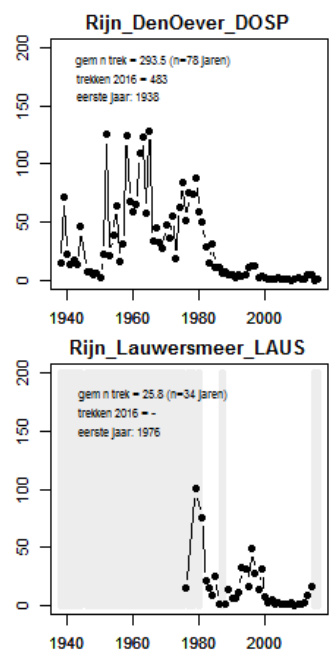

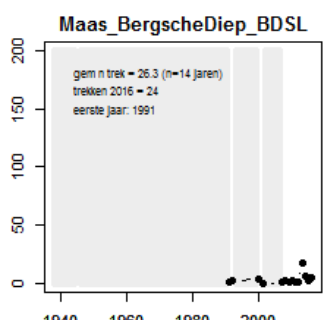

$1940 \quad 1960 \quad 1980 \quad 2000$

Rijn_Harlingen_HTHS
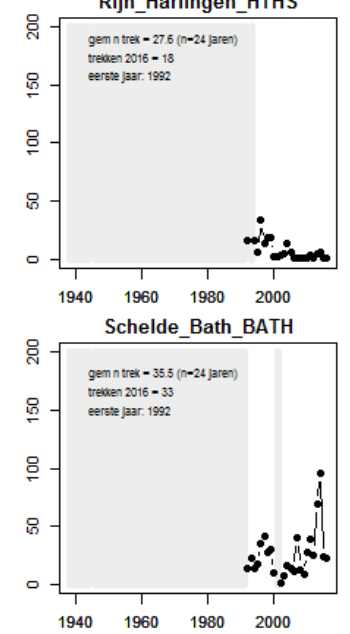
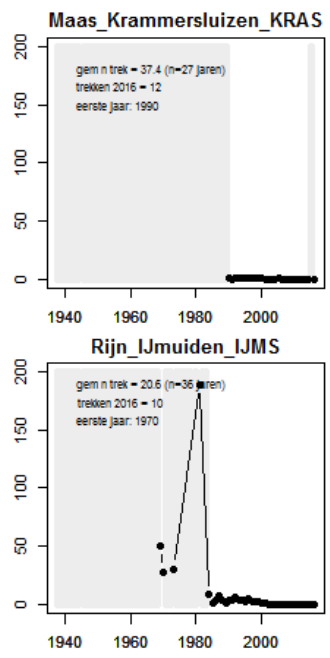

Figure 2-3 Glass eel index data 1938-2016. An index is calculated using data of the months April and May with hauls taken between 18:00 - 08:00 and at least six hauls per period. However, all locations are also sampled during the month March. Missed monitoring data are indicated with grey bars. 


\section{$3 \quad$ Glass eel monitoring projects along the Dutch Coast}

There are five larger monitoring projects using small $1 \times 1$ liftnets along the Dutch coast or at freshwater barriers: (1) "WOT Wageningen Marine Research", (2) "Ruim baan voor vissen", (3) "collaboration of different parties along the Noordzeekanaal", (4) "Collaboration of different parties of the South West Delta" and (5) "Monitoring Zeeuwse Eilanden". Note that even though the monitoring program 'Ruim baan voor vissen' project officially has ended (Table 1), some locations are still ongoing on the initiative of local water boards or volunteers.

The title of this chapter may suggest that all programs are executed along the Dutch coast. However in fact only three out of five are (or have been) fully carried out in a marine environment. The project in the Noordzeekanaal is completely 'fresh' (brackish) and another is partially fresh and partially carried out in a marine environment (South West Delta). In 2014 a program started at freshwater pumping stations, sluices and other (freshwater) barriers in the North Sea Canal (Noordzeekanaal). In 2015 a second program started at Zuid Westelijke Delta. Also here, many locations are at freshwater barriers. However, compared to the Noordzeekanaal, the Nieuwe Waterweg has an open connection to the sea and therefore, some of the location are located at the 'sea side' monitoring glass eel that arrive from the sea.

The three programs at marine barriers are: (1) the monitoring program of Wageningen Marine Research carried out along the whole Dutch coast and is the longest of all programs. This series started in 1938 at Den Oever after closing off the Zuiderzee. This unique series is still ongoing with several hundreds of hauls throughout the night, throughout the migration period on consecutive days. This in unique compared to all the other programs and time series. Moreover, this series is internationally unique and therefore valuable for policymakers and fisheries advice (ICES - WGEEL). Besides this location, but within the program, other locations have been monitored since the nineties. However, at these locations, the number of hauls are less compared to Den Oever. The second (2) monitoring project started in the North of the Netherlands (Ruim baan voor Vissen). This program has two periods: 2001-2003 and 2012-2015 for comparison and evaluations purposes. The final one (3) was initiated for one year in Zeeland at different pumping stations or other barriers for evaluation purposes.

In general most programs have been executed to evaluate management measures and not primarily to monitor a year to year index as is the case for the Wageningen Marine Research program. In the following paragraphs, each monitoring program will be briefly discussed with details about the monitoring program. Table 1 and 2 summarizes details about the monitoring programs: monitoring years in time series (Table 1 ) and location details, planned management measures, glass eel catch numbers, number of hauls and monitoring period (Table 2 ). 
Table 1 Summary of monitoring projects in Dutch waters since 1938. Black: multiple hauls, white: zero hauls. The program 'Ruim baan voor vissen' officially stopped in 2015, but some water boards continued or are planning to continue monitoring activities.

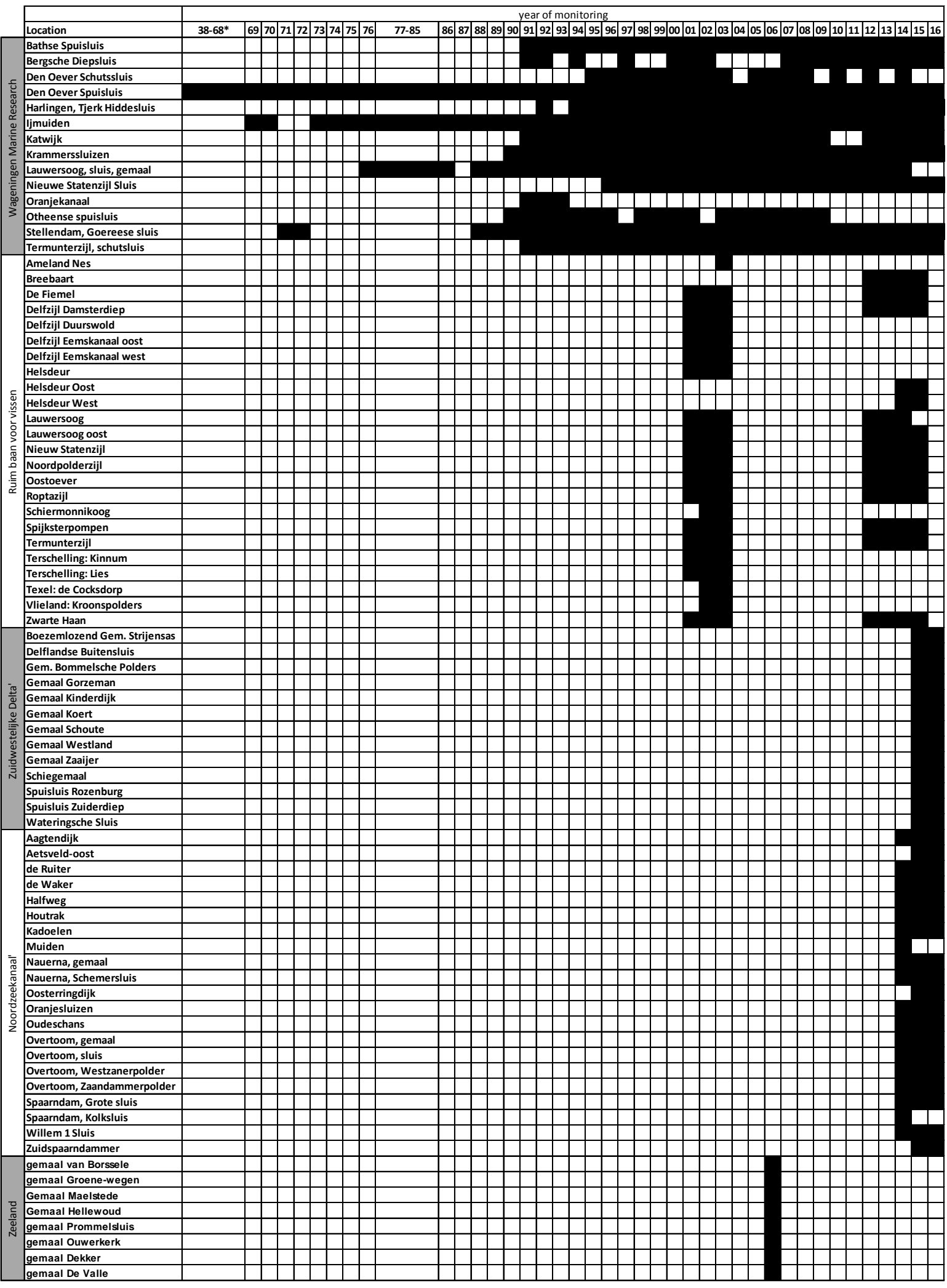

* In 1945 there was only one haul taken at Den Oever. 
Table 2 Summary of monitoring projects in Dutch waters with information about locations, monitored years, planned management measure, summarized catch numbers, number of hauls, monitoring period and reference. The program 'Ruim baan voor vissen' officially stopped in 2015, but some water boards continued or are planning to continue monitoring activities.

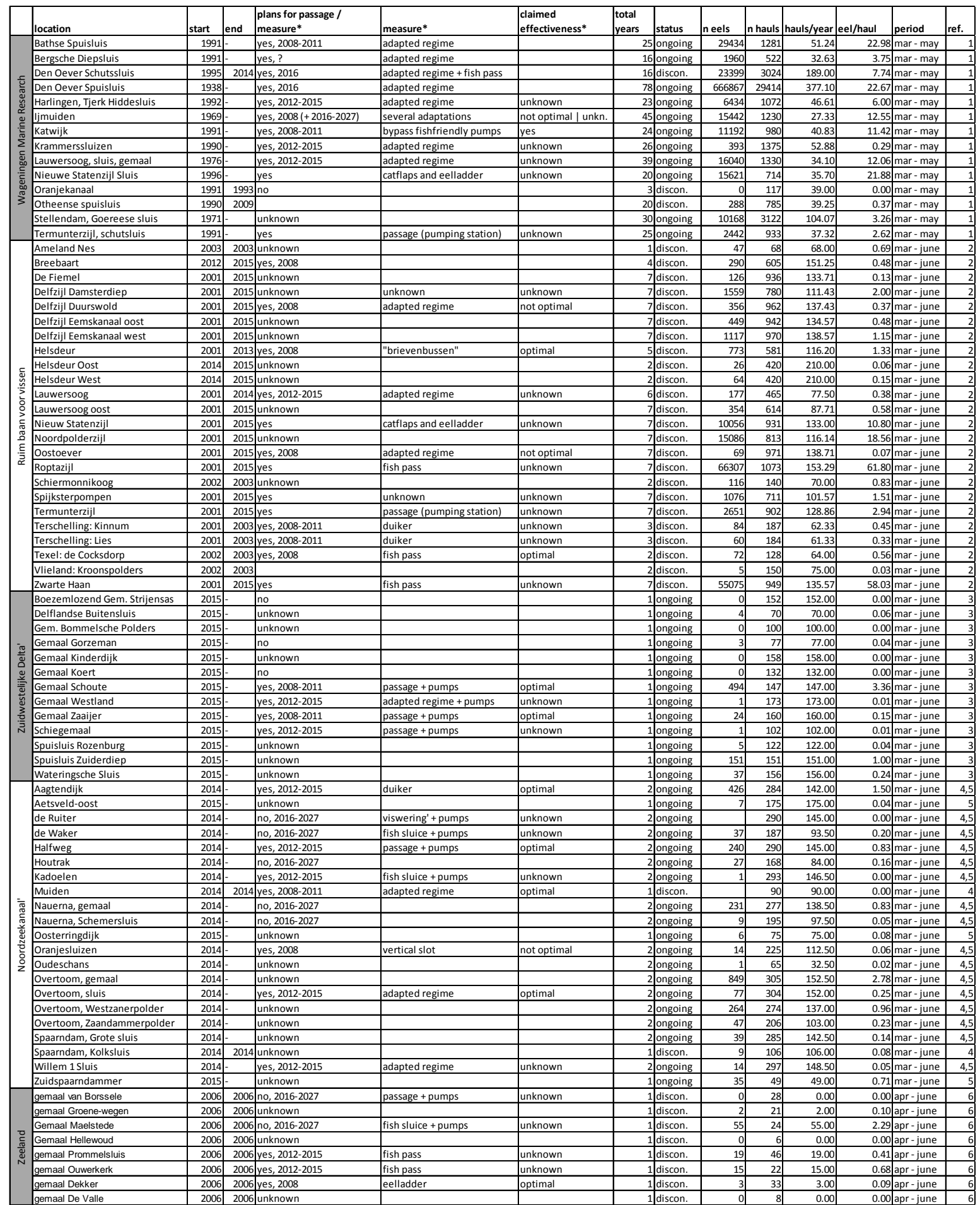

* http://www.sportvisserijnederland.nl/vis-water/vismigratie/ (sept. 2016)

1 IMARES

2 Wintermans $(2003,2015)$

3 Projectgroep samen voor de Aal (2015)

4 Werkgroep monitoring Noordzeekanaal (2014)

5 Werkgroep monitoring Noordzeekanaal (2015)

6 Winter et al. (2007) 


\section{Monitoring project: "WOT Wageningen Marine Research"}

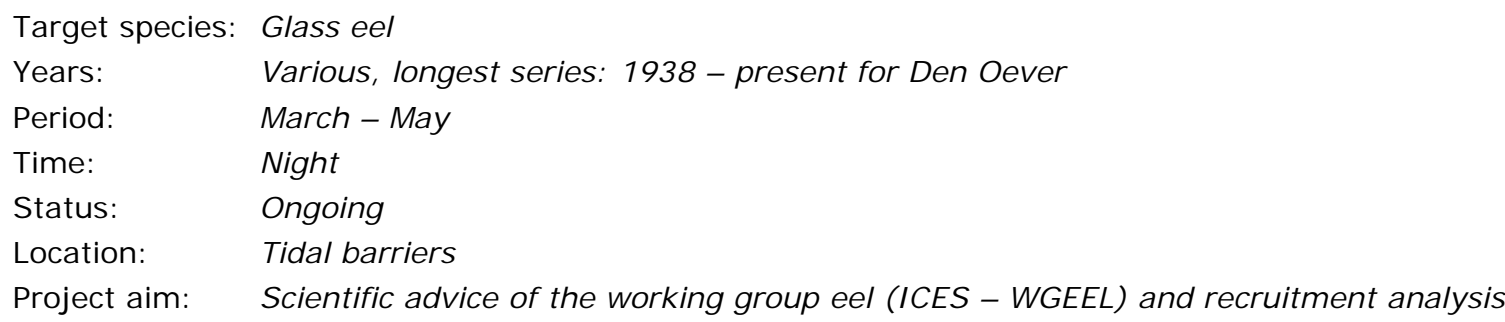

This project was initiated in 1938 after closing off the Zuiderzee with the Afsluitdijk. To compensate for negative impacts on fisheries, the operation of the sluices was adjusted to facilitate glass eel immigration (Dekker 2002a). The monitoring was executed by sluice personnel, in return for a small compensation. Later, the monitoring was executed by professional fisherman who were paid for their activities. At other locations (Table 1), the monitoring is executed by volunteers (e.g. waterboard members, fisherman) who all get a small reward and travelling costs. The monitoring at IJ muiden is executed by Wageningen Marine Research (WMR) personnel. During the programme, sampling at some monitoring locations is discontinued (Table 1). Sampling takes place during the night and focusses on glass eel abundance. All locations are at tidal barriers. Other species, besides glass eel, are not formally registered.

The data collected at Den Oever (discharge sluice), together with Katwijk, IJ muiden and Stellendam, are used for scientific advice of the working group Eel (ICES) and the analysis of recruitment trend (ICES 2016). The monitoring is carried out in March, April and May, but for index calculations only April and May are taken into account.

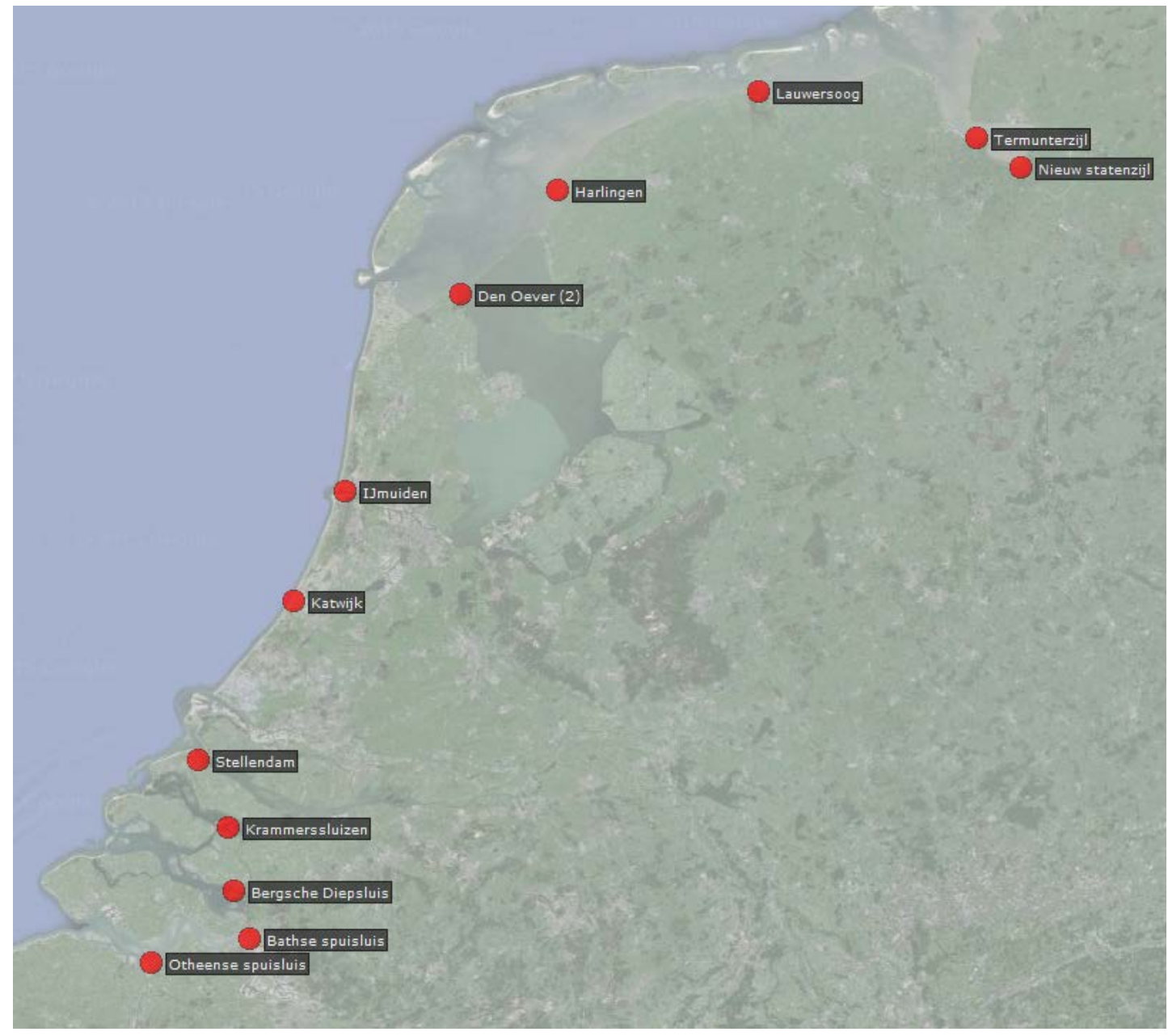

Figure 3-1 Monitoring locations of the monitoring project: "WOT Wageningen Marine Research" Location are situated along the Dutch coast. 


\section{Monitoring project: "Ruim baan voor vissen"}

Target species: Three-spined stickleback, glass eel, smelt, flounder larvae

Years: 2001-2003 and 2012-2015

Period: $\quad$ March - June, in some years monitoring started in February.

Time: Day and night

Status: $\quad$ officially discontinued, but some water boards continued on their own initiative (pers. com. G. Wintermans)

Location: Tidal barriers

Project aim: Increase knowledge on fish migration at tidal barriers and to promote measures for the improvement of immigration of glass eel and stickleback along the coast of the Wadden Sea.

This project initiated in 2001 and focuses on the North of the Netherlands (Wintermans 2015). The fieldwork was carried out by volunteers, water board members or the Dutch Angling Association. The project was coordinated by Wintermans Ecologenbureau (WEb). The program officially stopped in 2015, but some water boards continued monitoring activities. In general, the program comprises two monitoring periods: (1) 2001-2003 and (2) 2012-2015. Sampling took place during day and night since other species were also sampled and registered. In addition to the monitoring at the marine side of a barrier, there were also samples taken at the 'fresh water' side during the first monitoring period. Most of these samples did not caught glass eel.

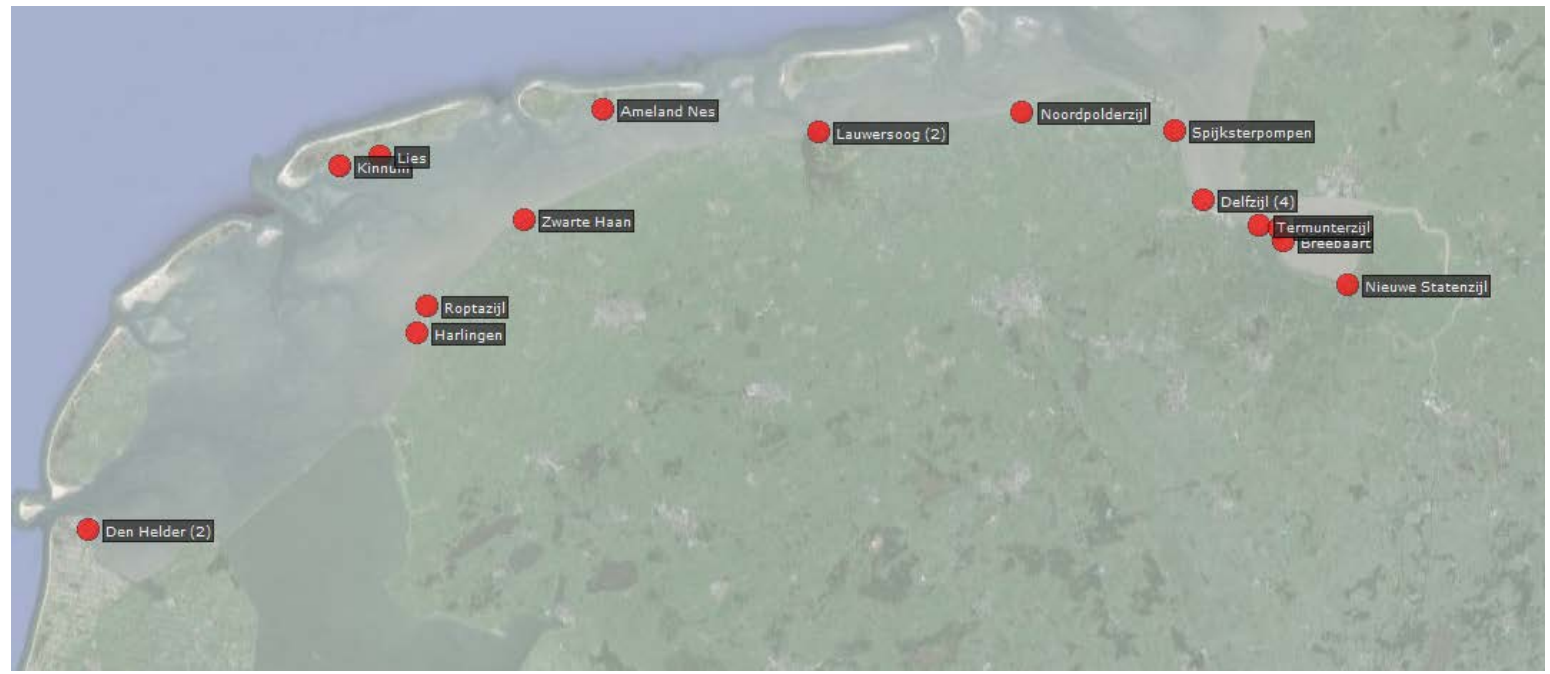

Figure 3-2 The majority of monitoring locations of the monitoring project: "Ruim baan voor vissen" which was executed from 2001-2003 and 2012-2015. Location are situated at tidal barriers in the Dutch part of the Wadden Sea. 


\section{Monitoring project: “Zuidwestelijke Delta”}

Target species: Glass eel, three-spined stickle back

Years:

$2015-2017$

Period: March - June, Monday and Thursday

Time: Night, half hour after sunset.

Status: Running

Location: Tidal barriers and freshwater barriers (brackish)

Project aim: Increase knowledge on fish migration in relation to management of sluices, pumping stations and fish passages. Public awareness and participation.

This project is a collaboration of waterboards, RAVON foundation and World Fish Migration Foundation and is initiated within the program: "Programma Vismigratie Nieuwe Waterweg". The aim of this project is that the gained knowledge will be used for management optimization and prioritizing of sluices, pumping stations, fish passages. Moreover, the project contributes to public awareness and participation of fish migration. Catches are, except for four locations, extremely low with zero or only a few glass eel. However, 2015 may be a 'bad' year class for eel taking into account the lowest index value in 2015 at the extensive monitoring of glass eel at Den Oever since the starting of this monitoring project in 1938. On the other hand, since there is only one year of data and no reference, catches may be low due to a low barrier effect of the locations. In other words, eel abundance may be high, but catches (density) are low due to a low accumulation of glass eel in front of the barrier.

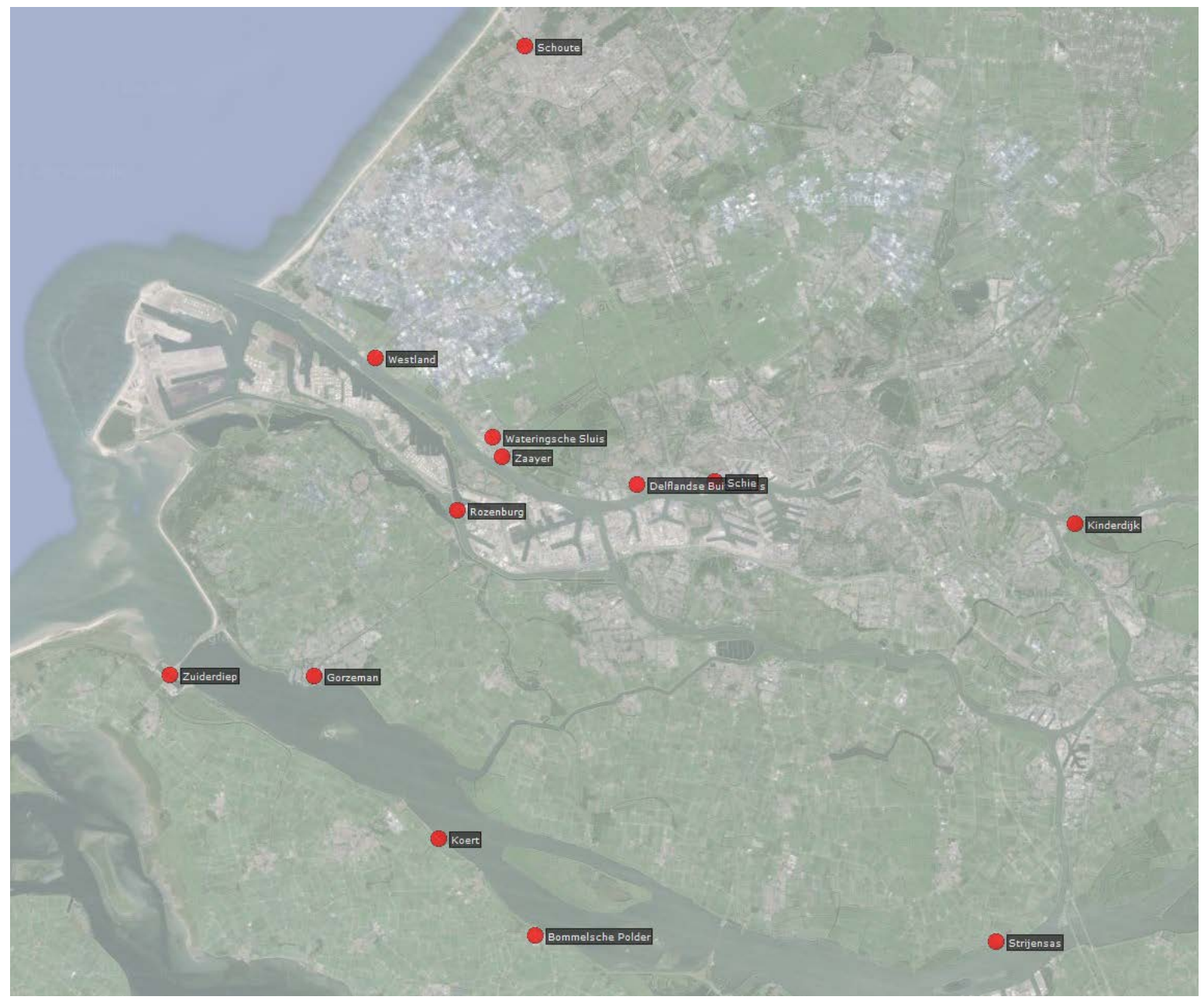

Figure 3-3 The monitoring locations at the Zuidwestelijke Delta. 


\section{Monitoring project: “Noordzeekanaal”}

Target species: Glass eel, three-spined stickle back

Years:

2014 - 2016

Period: $\quad$ March - June, Monday and Thursday

Time: $\quad$ Night, half hour after sunset.

Status: Running

Location: $\quad$ Freshwater barriers (some may be brackish)

Project aim: Increase knowledge on fish abundance. Insight in variation of glass eel and threespined stickleback in time and space. Public awareness and participation.

This project is a collaboration of waterboards, RAVON foundation and World Fish Migration Foundation. The aim of this project is that the gained knowledge will be used for management optimization and prioritizing of sluices, pumping stations, fish passages. Moreover, the project contributes to public awareness and participation of fish migration. Comparable to the program "Zuidwestelijke Delta" there are only few monitoring data with only one or two years. Contrary to the Zuidwestelijke Delta, catches are higher. However, index values (eel/haul) are quit low.

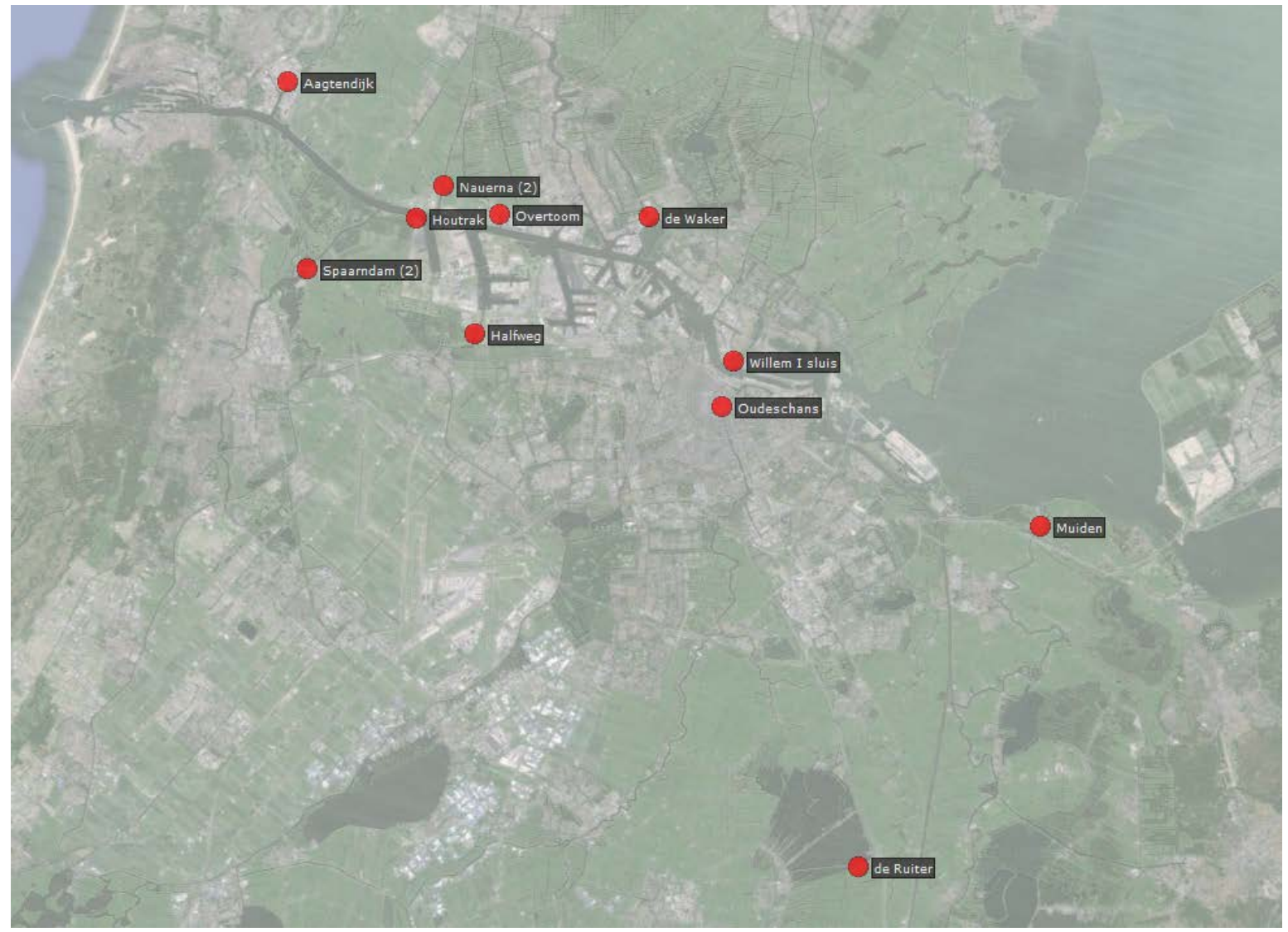

Figure 3-4 The monitoring locations at Noordzeekanaal. 


\section{Monitoring project: “Glass eel Zeeland"}

Target species: Glass eel, three-spined stickle back

Years: $\quad 2006$

Period: $\quad$ April - June

Time: $\quad$ Night, after sunset.

Status: Discontinued

Location: Mainly tidal barriers

Project aim: Management measure evaluation

This project was initiated by the waterboard "Zeeuwse eilanden". Since the year 1995, many management measures have been implemented to facilitate fish migration. This, one year program, was to evaluate the measures for glass eel migration. The glass eel monitoring was part of a larger analyses. The project contains a quick-scan of barrier effects based upon lift net monitoring and historic data (Winter et al. 2007a).

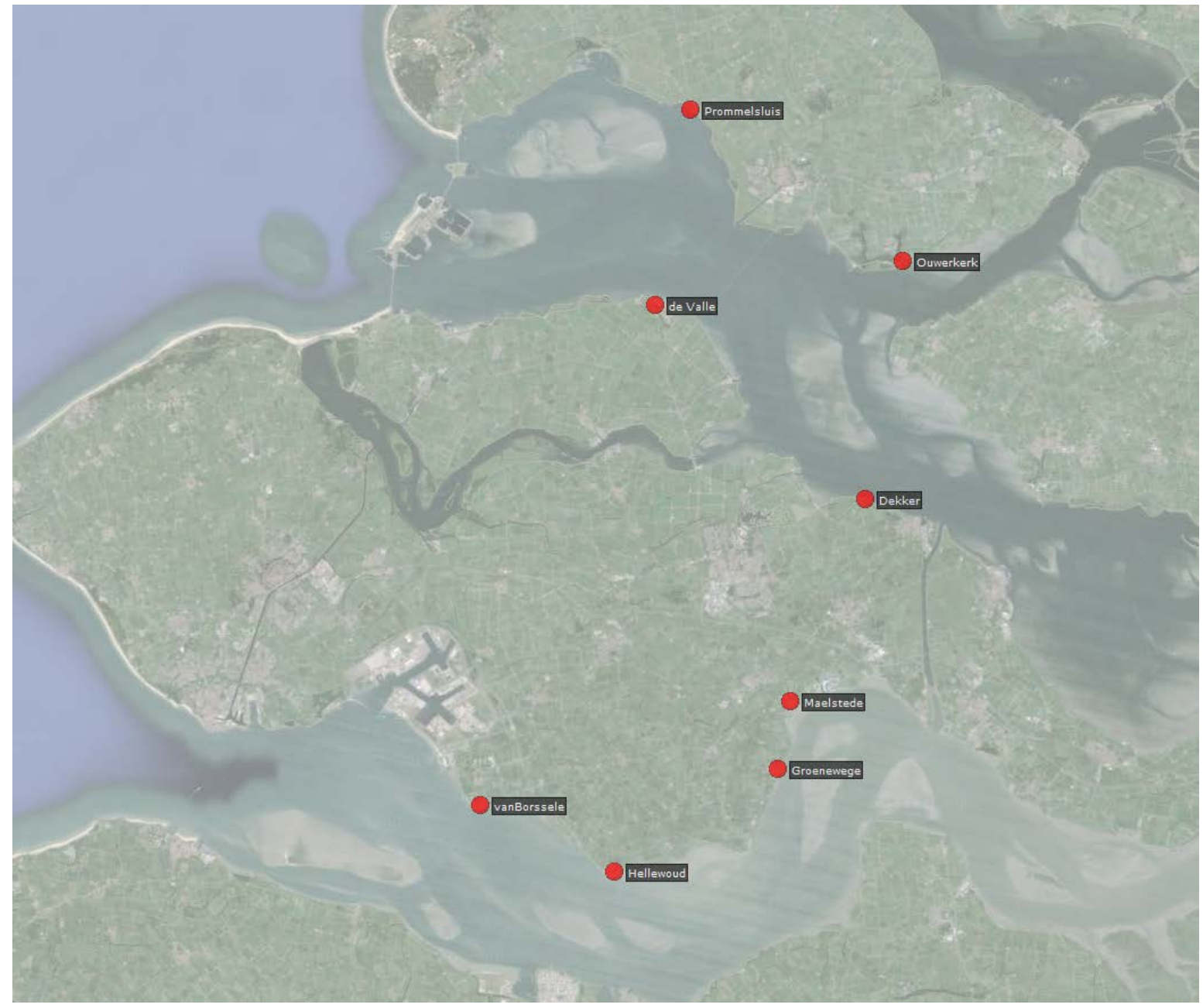

Figure 3-5 The monitoring along the Zeeuwse eilanden. 


\section{Discussion and conclusion}

Of all the monitoring projects WMR has by far the longest datasets of glass eel monitoring. And, for this reason, only this dataset is applicable to produce a national index since a trend analysis will be more reliable (chapter 4 ). The program of WMR has been especially designed for glass eel. All other programs have been registering also other small diadromous fish like three-spined stickleback. This is why the 'ruim baan voor vissen' project also sampled during the day. Contrary to this latter project, the other projects sample during the night since it is assumed that many of the glass eel will migrate during the night. However, all of them, except for Den Oever, sample after sunset and take multiple hauls within a short time window. E.g. this is also the case at 'the other WMR locations'.

Some locations of the Noordzeekanaal and the Zuidwestelijke Delta have more hauls (>100) per season in comparison to the WMR dataset (except Den Oever). This makes more detailed analysis possible. However, these locations are located at secondary, 'freshwater' / brackish, barriers. For index purposes, it is better to monitor glass eel at primary, tidal (marine), barriers to have less interference and cumulative effects as a results of consecutive barriers (see chapter 6). These locations are however relevant for reference purposes for the monitoring at IJ muiden. At this location few to no glass eel is caught (Chapter 6 will describe this further). Contrary to the locations at the Noordzeekanaal, locations at the Zuidwestelijke Delta are in potential relevant locations for a national index since many of them are nearby and directly connected to the sea (e.g. Westland). This project started in 2015 and thus only two years of monitoring have been executed and is therefore omitted for in our analysis.

The locations near the Wadden Sea ('ruim baan voor vissen') are potential relevant for a national index analysis. However, there are two periods: 2001-2003 and 2012-2015 with a data gap in between. For index trend analysis a continuous monitoring series is preferred. Moreover, many management measures may have caused major changes in local glass eel density and spatio-temporal dynamics (Table 2). However, the effect of the measures on local glass eel densities and the relation to monitoring catches is largely unknown. The project in Zeeland is also omitted in our analysis since there is only one year of data available.

Of all the locations, Den Oever is the location with the largest number of hauls per season and produces the most extended, and probably most precise, year to year glass eel index. Moreover, this location takes into account multiple hauls per night at different points within the tidal cycle on consecutive days. All other locations have the potential to miss or overrate migration peaks during the migration and monitoring season. In addition to this, the data of Den Oever, has registered in the database of WMR, includes number of glass eel per haul since 1938, whereas most of the other locations aggregated catches are registered of multiple hauls. For this reasons, the data of Den Oever was used to study abundance in relation to water levels as an effect of tidal currents (chapter 5). 


\section{$4 \quad$ Exploration of a national glass eel trend analysis}

\subsection{Data availability national glass eel trend}

As described in the previous sections, the glass eel index is an indicator that is used to assess the state of the recruitment of glass eel and to assess trends over time. In the Netherlands the glass eel index is calculated for each monitoring site separately. Of all the monitoring projects, Den Oever is the location with the largest number of hauls per season. Moreover, this location takes into account multiple hauls per night (one hauls per hour: 22:00-05:00) at different points within the tidal cycle on consecutive days. However, it is debated whether all locations should be consolidated to produce one national index. This chapter evaluates the use of data from additional monitoring sites in the Netherlands to establish a 'national' glass eel index. For this purpose, it was also investigated whether it is possible to implement the Working Group EEL (WGEEL) approach. This is currently used by ICES to combine glass eel indices from different countries in an overall trend assessment (see Annex 8 to the ICES WGEEL report, 2016). As section 4.2 will explain in more detail, the WGEEL approach was not applicable for the WMR data. However, we use, compared to the internationally accepted ICES approach, a slightly different approach with our data. The principles of this approach are basically the same.

To explore a national glass eel trend analysis with available data, the first step was to identify useful monitoring data (chapter 3). Since many monitoring programs have only recently been started, the Wageningen Marine Research WOT monitoring program seems to be the only suitable dataset available to explore a national glass eel analysis. Moreover, raw counting data (number of caught glass eels) per net lift is available for each of these locations. The date is available for all observations, the time for most. In principle, all available (Wageningen Marine Research) data are included in the analyses, However, locations at which for the available period no glass eels were observed or where there are no more than 100 hauls in total, are omitted from the analysis.

\subsection{Evaluating the WGEEL approach}

Although it would have been convenient to implement an internationally accepted approach for combining glass eel indices, it was not possible to apply the methodology to our data set. To understand this, we will first briefly describe how the WGEEL method works.

- Glass eel indices as provided by each country is first standardized, by dividing the numbers by the average number for each country for a fixed reference period. This way, the average number in the reference period is always 1 , for each country.

- Regions with contrasting trends (i.e., North Sea and elsewhere in Europe) are raised separately.

- Smoothed year indices are calculated based on the standardized numbers, using a GLM (Gamma distribution family with log link). Zero's in the data are omitted as they cannot be included in the selected model. The two specified regions are included as explanatory variable.

- An overall trend is based on the geometric mean of the two regions.

This approach does not work with our data for the following reasons:

- The data cannot be standardised using a common reference period for all locations, as data availability (and the period in which it is available) varies a lot.

- Contrasting trends are observed in the WMR data. It's not easy, and not preferable considering the small scale, to split the data into sub-regions based on these contrasting trends. 
- The GLM model selected in WGEEL does not work very well with the (non-standardised) raw data we have here, mainly because there are many zeros (almost a third of all observations) in our data. Omitting these zeros from the analyses will cause a heavy bias. Furthermore, we will lose statistical power when we raise our data before analysis.

We are limited by what we can do with the available data as described above. As stated before, we use a slightly different approach with our data. However, the principles are basically the same.

\subsection{Analyses of data}

In the present study the following approach was used. For the analysis of catch data (further referred to as 'count') it is common practice to assume a Poisson distribution of the numbers. In the glass eel counts there are far more zeros than can be expected from a Poisson distribution. This happens when the eels are not distributed homogeneously in space and/or time, or when the absence and presence of eel is affected by some factor. For glass eel both situations probably apply. Both however require a different modelling strategy: for the first situation overdispersion can be modelled by for instance assuming a negative binomial distribution of counting data; for the second situation a zero-inflated model could be used. In the present study the first option was used as this gave the best fit to the data. The following Generalised Linear Model (GLM) model (with a negative binomial distribution family with log-link) was fitted for each location individually (we can't combine all locations in one model due to overparameterisation of the model):

count $\sim$ year (as factor) + period (as factor) + offset (number of net lifts)

The model thus intends to explain the number of glass eel caught (count), from the year in which they were caught, the period in which they were caught and the number of net lifts that were used to catch them. Based on the date of the observations, three periods were defined: 1) from January up to March, 2) April and May and 3) June and later. These periods were included in the model as period (as factor). This model was used to predict the best estimate for each location of the number of glass eel that you will catch with a single net lift in the period of April and May in a specific year. April and May are commonly used to calculate the index value with a traditional approach (Sluis et al. 2014).

These predictions will still contain 'holes' for the locations and years in which no observations (i.e., no effort) are available. For each location, these holes in model predictions are filled with linear inter- and extrapolation. Beyond the range of available years, the counts are assumed constant and equal to the number available for the closest year.

The model predictions for each location are combined for each year by simply taking the geometric mean, where each location is weighted by the square root of the total number of net lifts for those locations (i.e., locations with high sampling effort are included with more weight). This provides a combination at a national level of all available glass eel index. In the discussion we will address whether this is the best way forwards.

\subsection{National trend of glass eel}

As for many locations the historical period covered is limited, and thus constant extrapolations where used (Figure 4-2). This causes the 'national' geometric mean to flatten in this period (roughly the period before 1980). Due to the weighing of the 'national' geometric mean with the effort, the 'national' index is strongly correlated to the index estimated for Den Oever (Figure 4-4), which is the location with the highest sampling effort (hundreds of hauls per year, Figure 4-1). In addition, a national index excluding Den Oever data was also calculated. When a national index was calculated without the data of Den Oever (Figure 4-2), the data showed similar pattern as compared to a national index with Den Oever. However, expected values are somewhat lower and the decline stronger when data of Den Oever is excluded. 


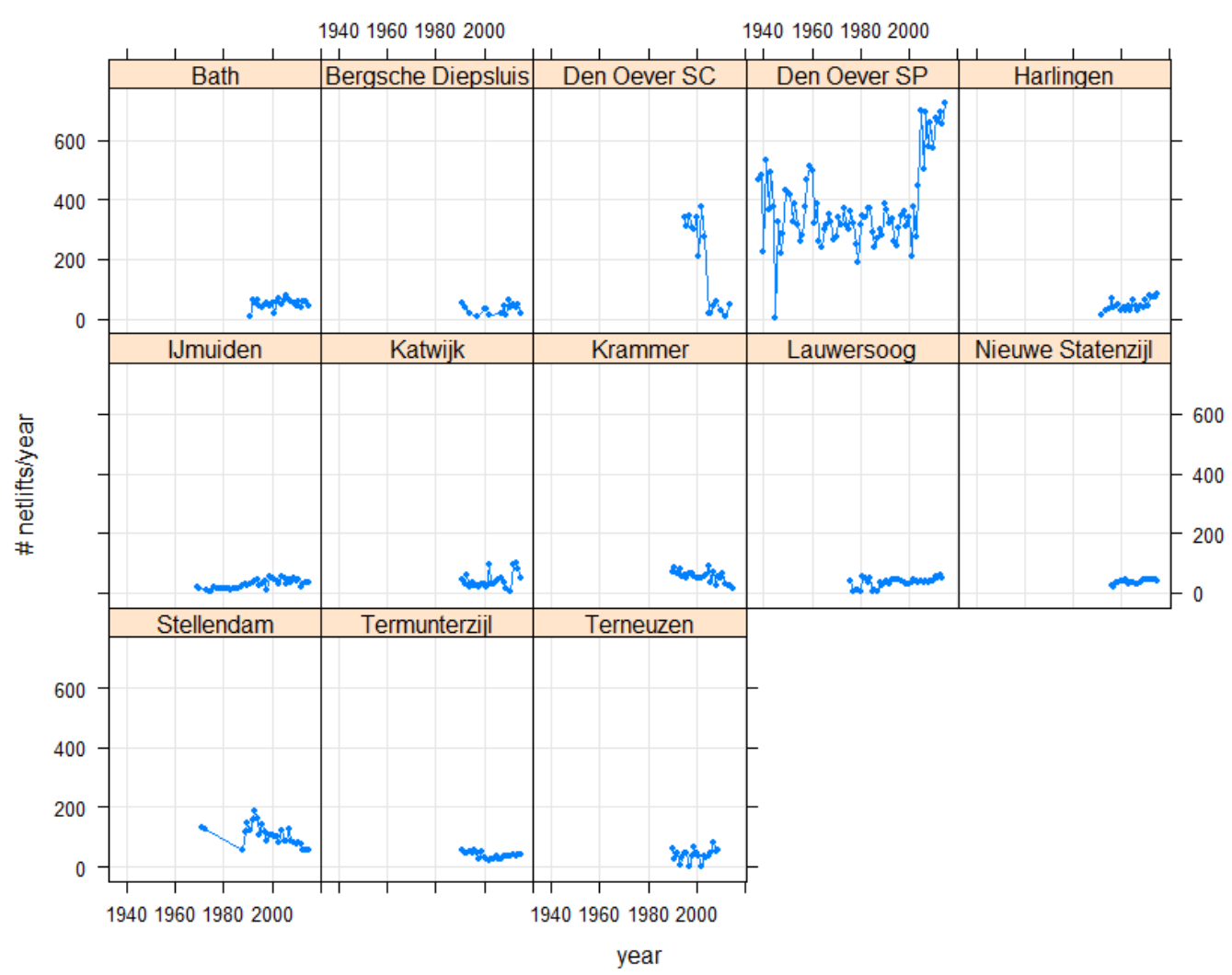

Figure 4-1 Number of hauls per year per location.

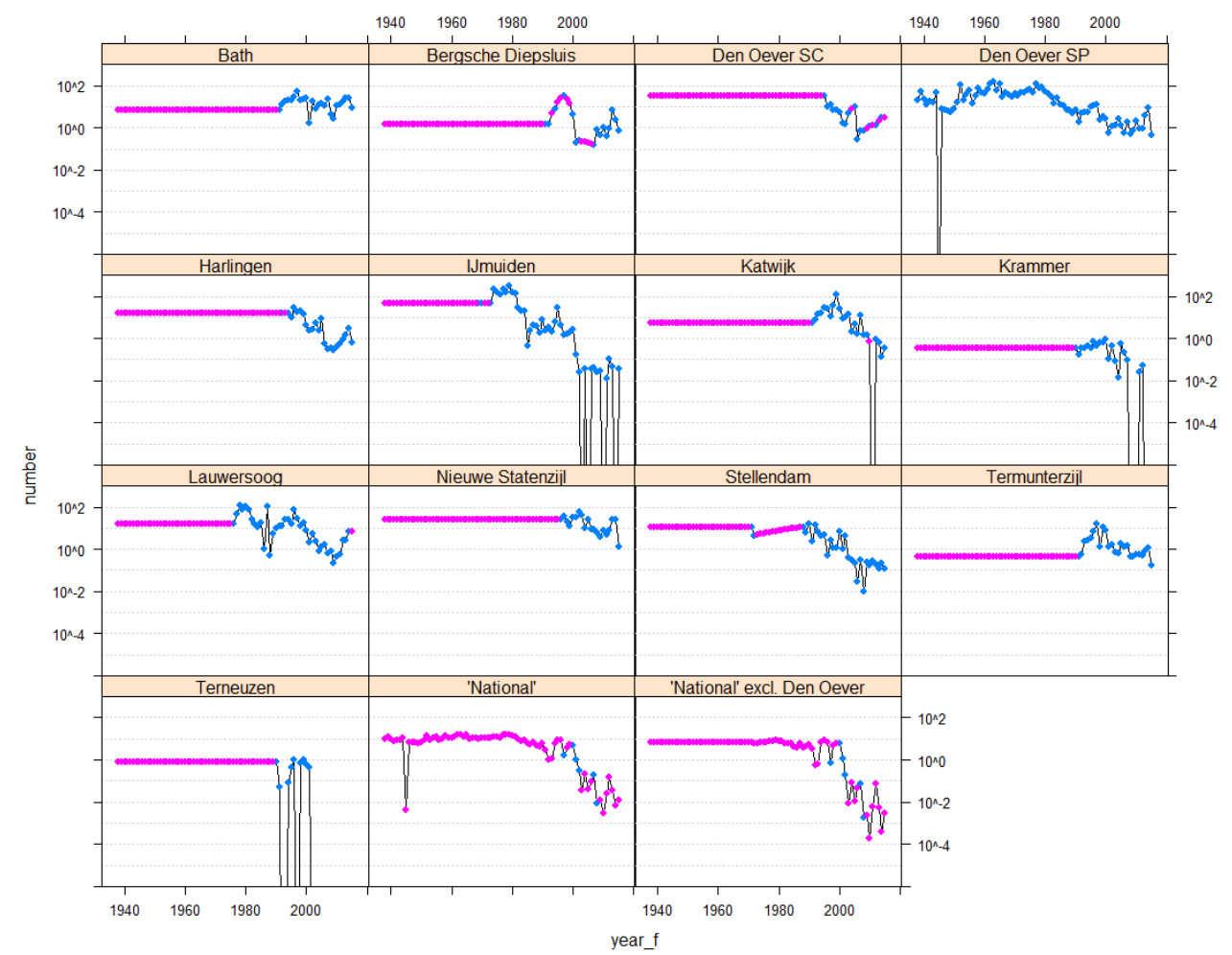

Figure 4-2 Glass eel indices (expressed as number of individuals per haul) estimated with GLM for each location (blue dots) and inter- and extrapolated indices (pink dots). Inter- and extrapolation is only done for years for which no observations are available. The panel labelled 'National' shows the weighted geometric mean of all locations (where pink dots indicate that for any of the underlying locations the data were inter- or extrapolated). Y-axis is on a logarithmic scale, extremely small values are outside the plotting range. 


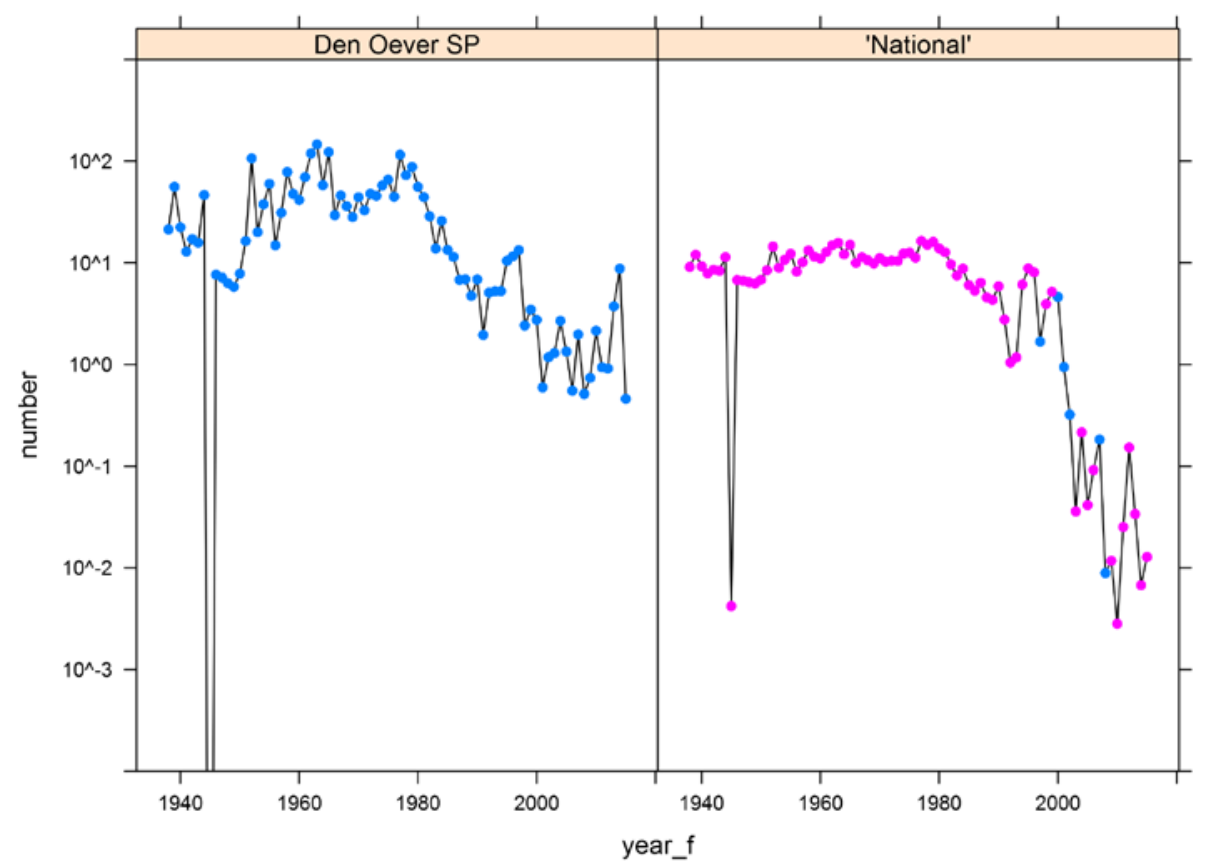

Figure 4-3 Glass eel indices (expressed as number of individuals per haul) estimated with GLM for Den Oever (spuisluis) and the 'National' data. The 'National' shows the weighted geometric mean of all locations (including Den Oever) with pink dots showing where for any of the underlying locations the data were inter- or extrapolated). Y-axis is on a logarithmic scale, extremely small values are outside the plotting range. When numbers get low, correlation becomes less as locations other than Den Oever will weight relatively more.

To visualize the correlation between the series, the data has been divided into two series: a series before 1990 and a series after 1990 (Figure 4-4). Before 1990 the 'national' index is dominated by the data obtained by Den Oever, once that data is included (Figure 4-4 top left). The index before 1990 is dominated by the horizontal extrapolation of the locations other than Den Oever (Figure 4-4 bottom left). After 1990, other locations are more of influence in the index with and without Den Oever (comparing Figure 4-4 top right and bottom right). The decreasing trend seems more abundant at the other locations compared to Den Oever (Figure 4-3).

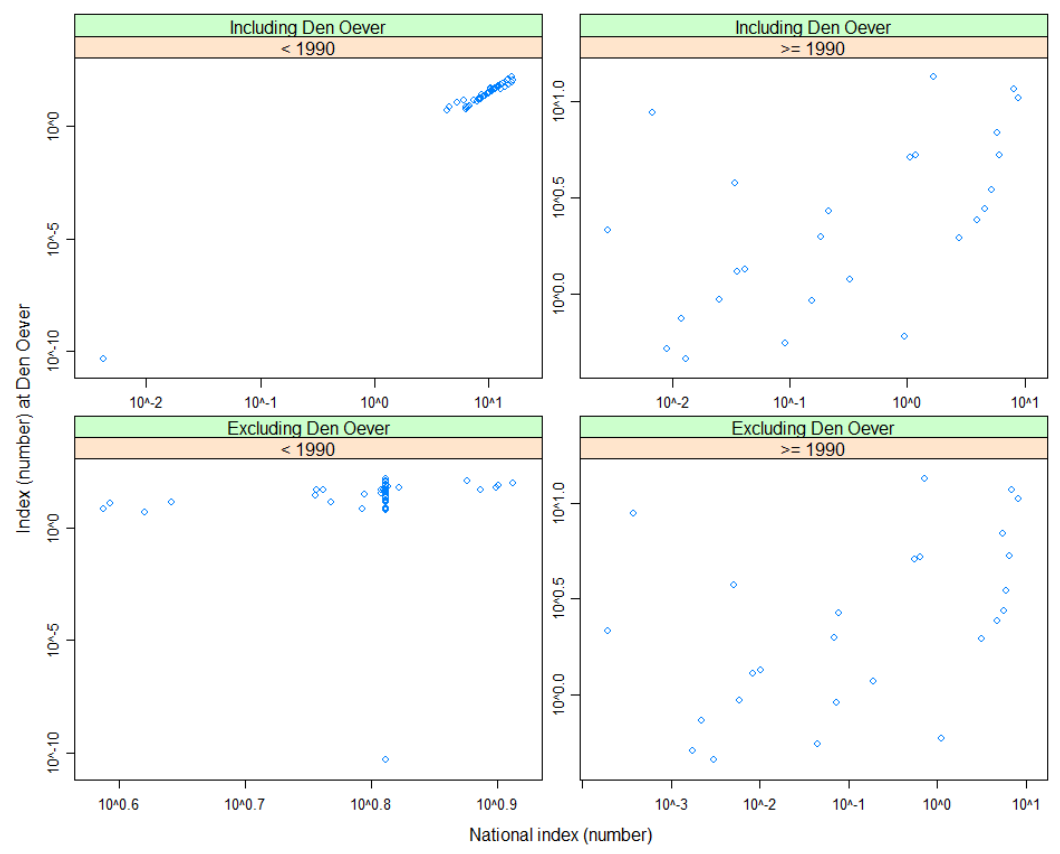

Figure 4-4 Correlation of 'national' index before 1990 and after 1990, including and excluding Den Oever. 


\subsection{Discussion, conclusions and recommendations}

We conclude that the internationally accepted WGEEL approach is not directly applicable to the raw data that is available within the Netherlands. However, similar principles can be applied. Data from different locations can be combined into a single 'national' index, but it is questionable if this approach is an improvement to just using the best sampled location. This is because:

- The interpolated glass eel indices are uncertain. The extrapolated estimates even more so, as they are more or less speculative. This uncertainty cannot be quantified.

- By averaging the locations, the uncertainty introduced with inter- and extrapolation is propagated in the overall index. Creating even larger (but hard to quantify) uncertainty.

- The geometric mean is weighted by the sampling effort, resulting in a high correlation between the resulting 'national' index and the index at the best sampled location (Den Oever). This raises the question whether it is worth introducing (largely unknown) uncertainty from the other locations, where the resulting index is very similar to that of the location with the highest sampling effort where in addition the uncertainties are known.

Given the considerations listed above, it is recommended to use Den Oever, in the current situation, as a representative location for establishing a national glass eel index. However, as other locations show contrasting trends, we advise to keep monitoring those as well, to nuance the trend observed at Den Oever. Moreover, it is advised to select locations where no alterations in migratory opportunities have taken place, and continue a few longer lasting series. These can be compared to Den Oever. Other improvements can be made in estimating the glass eel index at Den Oever, by including explanatory variables in the GLM such as the local conditions of the sluices (e.g. discharge events), weather conditions and tidal information. This way, noise created by those variables can potentially be eliminated in the estimates. Another recommendation is to intensify monitoring effort at some other locations to ensure multiple site index analysis in the future. 


\section{$5 \quad$ Relation of glass eel abundance and tidal water levels at tidal gates}

\subsection{Data availability and data processing}

\subsubsection{Glass eel data}

The long-term data series at Den Oever is by far the most extensive dataset of all the glass eel monitoring projects (Table 1 and Table 2). This dataset contains data throughout the night with multiple hauls on consecutive days and throughout the migration period (March - May). As stated before in this report, this dataset is primarily used to calculate the yearly index value. However, the dataset is also useful to analyse behavioural patterns of glass eel at tidal gates in relation to tidal currents. These relations can potentially be used to reduce variation in the index even more by correcting for this variation.

For this analysis we used the last 16 years of glass eel data at Den Oever (2000-2015). Data between 19:00 - 05:00 in the months March, April and May, were used for this analysis. For this analysis all nights (multiple hauls) where no eel was caught, were omitted from the dataset. In other words, when no glass eel was caught during one sampling night ( $~ 8$ hauls | 19:00 - 05:00), it was assumed that the absence of glass eel was not a result of tidal currents but other (e.g. mismatch migration period). This resulted in 6520 hauls in total or 408 hauls on average per year. To compensate for strong and weak year classes and migration peaks, all catch data was made relative: each night was considered as one 'catch unit'. The data of the units, was made relative (0.0-1.0). In other words, the number of eel caught during the night was summed and normalized to 1 . This makes the number of eel per haul (of that night) relative. Since this approach will give a relatively large weight to nights with only one or a few eel, the final analysis was compared with nights were at least 1,10 or 50 glass eel were caught.

\subsubsection{Water level data}

The tidal water data was obtained from live.waterbase. $\mathrm{nl}$ for all monitoring years (2000-2015). Water level was measured each 10 minutes during 24 hours for the whole period. Data manipulations followed roughly three steps: (1) distinguish rising and ebbing tide throughout the whole dataset. Irregularities (e.g. due to wind and waves) in the water level data set were flattened out, using the loess function (span $=0.00009$ ) in $\mathrm{R}$ (

Figure 5-1). High water levels (blue dots) and low water levels (green dots) were identified and used to calculate the relative position of each water level measurement.

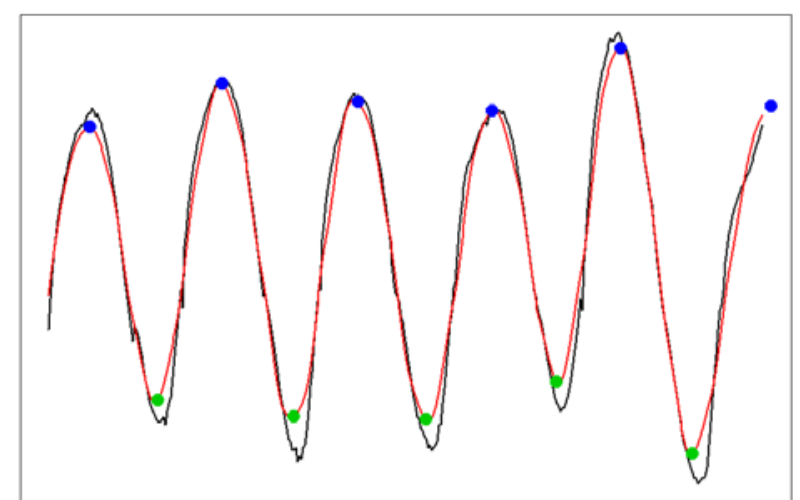

Figure 5-1 Example of the tidal cycle. Black line: observed water levels. Red line: predicted line. Blue dots predicted high water level. Green dots: predicted low water level. 
(2) Subsequent to this step, the water level data were made relative (0-1) per tidal cycle (low water high water - low water). By doing so, differences in water levels between days were compensated and high water levels were always considered as high water independent if this level was lower in comparison to the previous cycle.
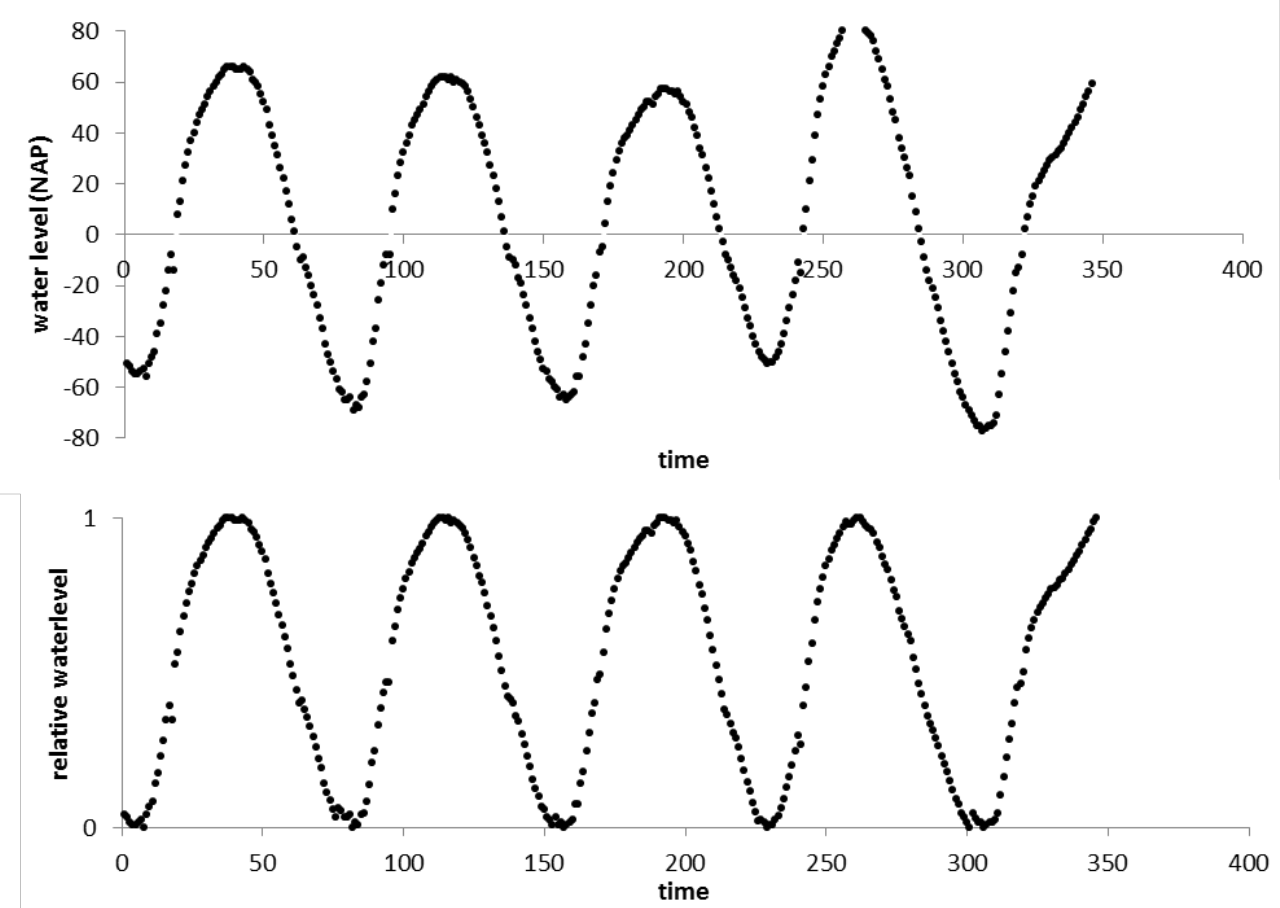

Figure 5-2 Tidal cycles observed (upper figure) and when made relative (lower figure).

The final step (3) was to divide each cycle in 20 sections distinguishing rising tide and ebbing tide (Figure 3-4). Some data was removed from the dataset, due to lacking of water level data $(n=388$ hauls). After data processing the datasets were merged based on date and time, taken into account summer and winter time.

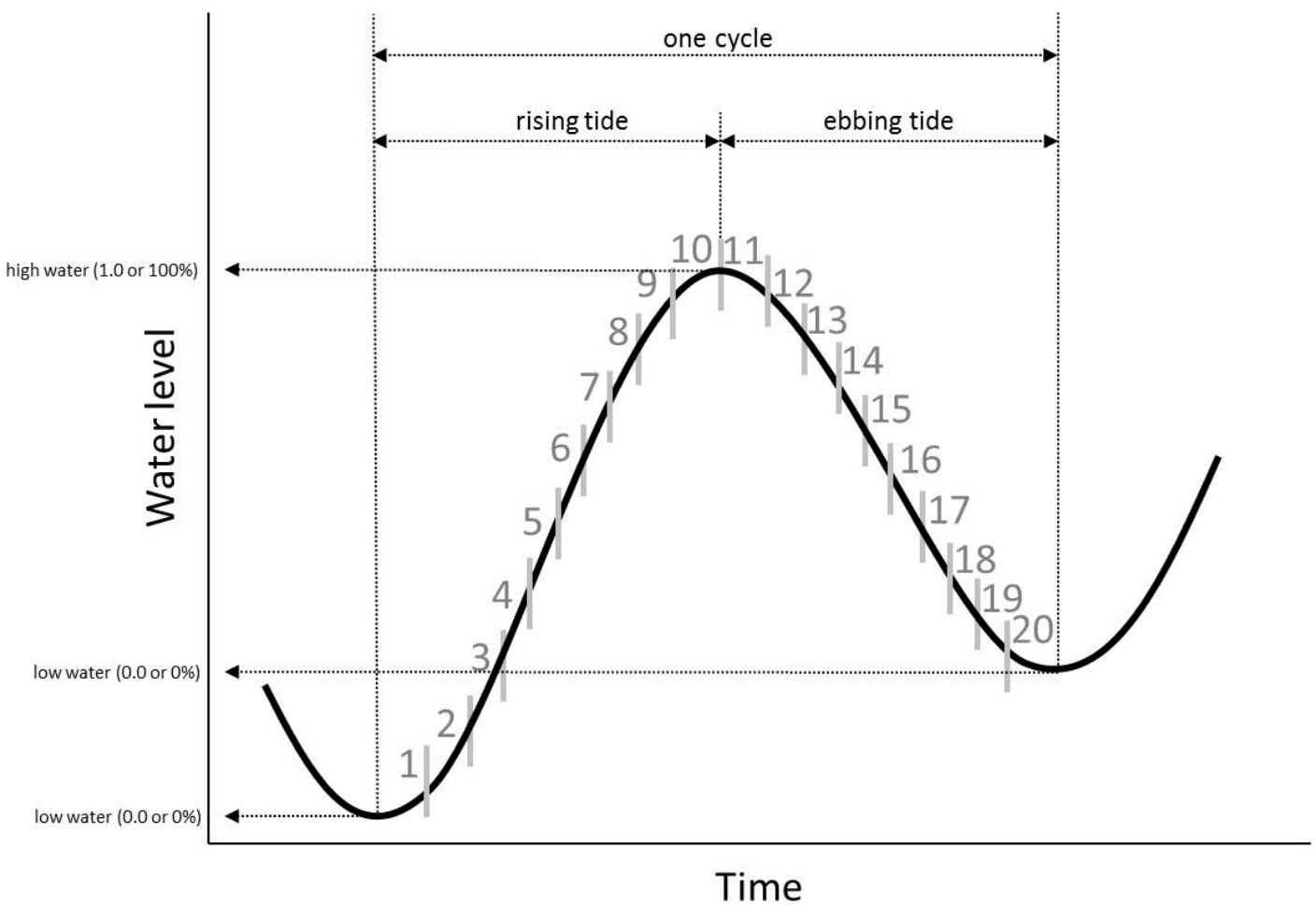

Figure 5-3 A tidal cycle with low water, high water and low water. Each cycle was made relative 0.01.0 distinguishing rising and ebbing tide, and divided into 20 section for further data analysis. 


\subsection{Relation eel catches and tidal currents}

The highest number of eel is caught during high tide and the lowest catches are during low tide (Figure 3-5). The catches are increasing with rising tide and slowly decreasing during ebbing. The catches are slightly larger after high tide, compared to rising tide.

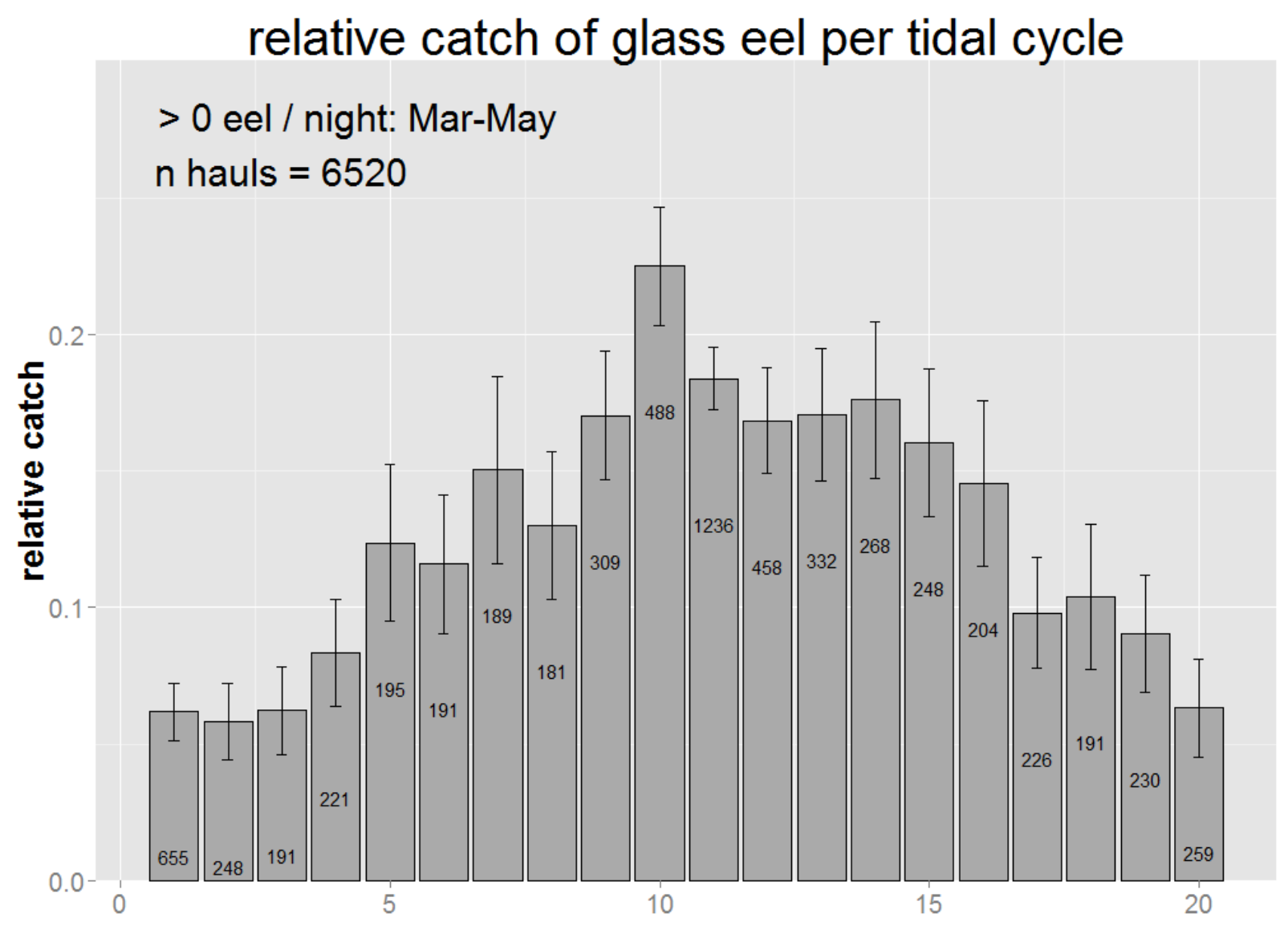

Figure 5-4 Average (relative) catches per section in the tidal cycle at the tidal gates of Den Oever. The number of hauls is 6520 limited to $>0$ eels per night ( $\sim 8$ hauls). Error bars show $95 \%$ confidence interval. $^{1}$

When the dataset is limited to nights were more eels were caught, e.g. $>10$ eel per night ( $~ 8$ hauls), a similar pattern is observed (Figure 5-5). It occurs in $40.9 \%$ of the nights that the sum of the catch (multiple hauls) are above 10 eel. Results show increasing catches during rising tide, the peak during high tide and slowly decreasing catches during ebbing tide.

During nights with many glass eel, e.g. $>50$ eel per night ( $>8$ hauls), the catches are more or less similar during the whole tidal cycle. There is a weak but certainly no clear peak during the tidal cycle visible and eels are caught throughout the tidal cycle in more or less comparable fractions (Figure 5-6). It occurs in $6.7 \%$ of the nights that the sum of the catch (multiple hauls) are above 50 eel. Glass eel are caught during the whole night with a peak during midnight (Figure 5-7).

\footnotetext{
${ }^{1}$ Note that varying water volumes as a result of tidal water levels were not taken into account in the analysis. In general the sampled water volume during high tide is larger in comparison to low tide, since the net will be lowered to the bottom of the location. When glass eel is equally distributed along the (vertical) water column, a larger sampled water volume (high tide) will automatically contain more glass eel. However, since distribution of glass eel at this location is unknown, it is assumed that water volume and absolute abundance of glass eel at the sampling location are independent.
} 


\section{relative catch of glass eel per tidal cycle}

\section{$>10$ eel / night: Mar-May \\ $\mathrm{n}$ hauls $=2664$}

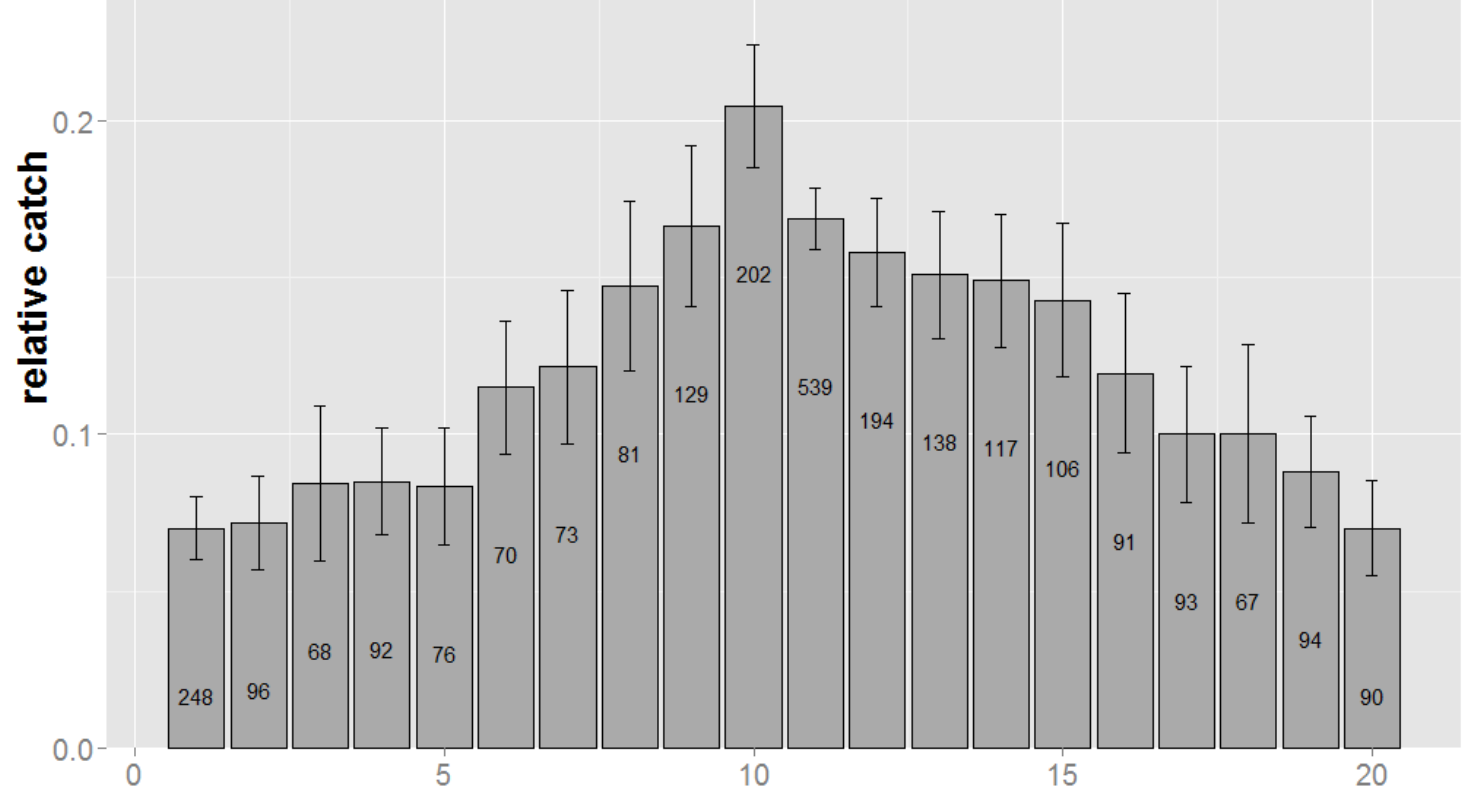

Figure 5-5 Average (relative) catches per section in the tidal cycle at the tidal gates of Den Oever. The number of hauls is 2664 limited to $>10$ eels per night ( $~ 8$ hauls). Error bars show $95 \%$ confidence interval.

\section{relative catch of glass eel per tidal cycle}

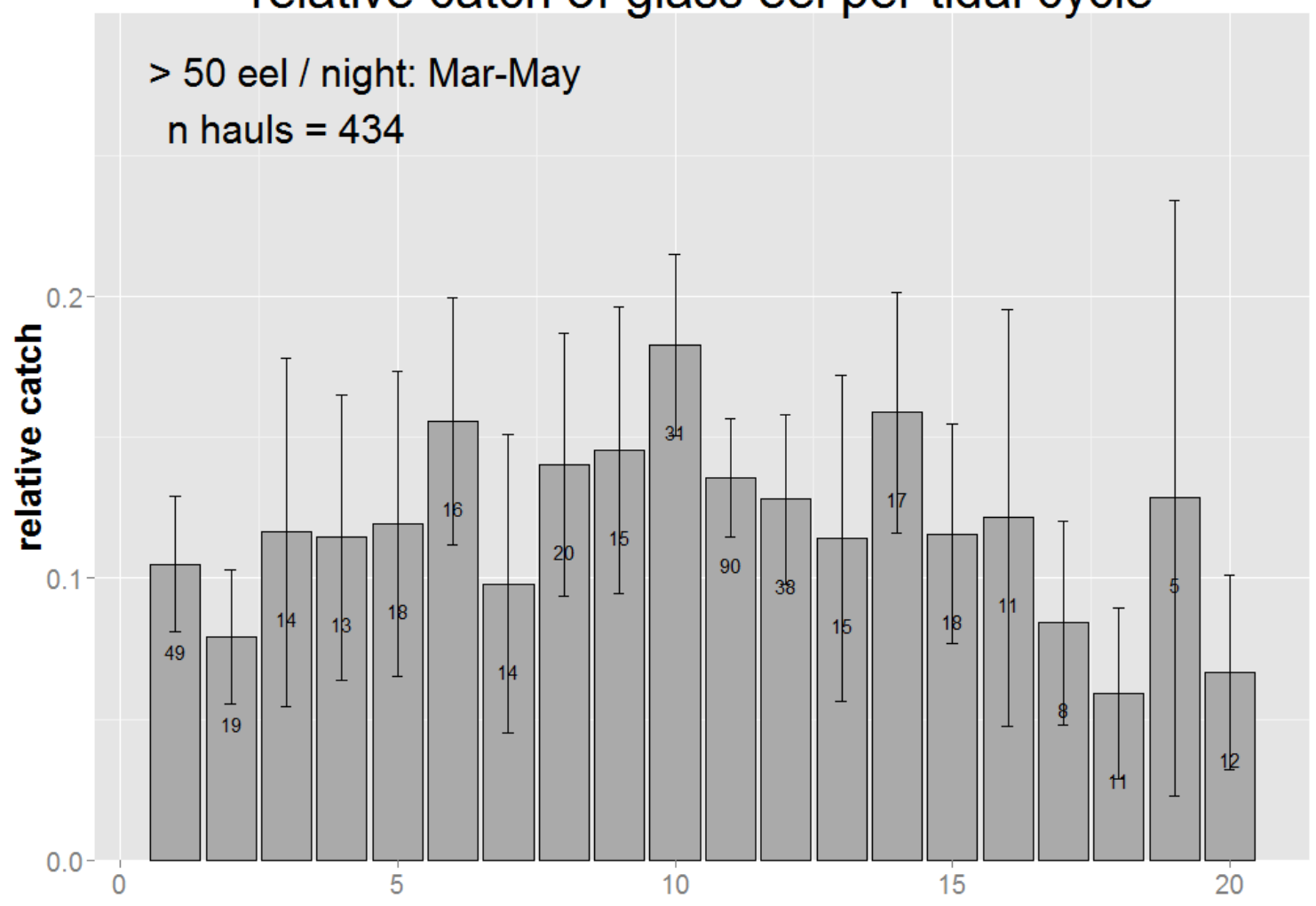

Figure 5-6 Average (relative) catches per section in the tidal cycle at the tidal gates of Den Oever. The number of hauls is 434 limited to $>50$ eels per night ( $~ 8$ hauls). Error bars show $95 \%$ confidence interval. 


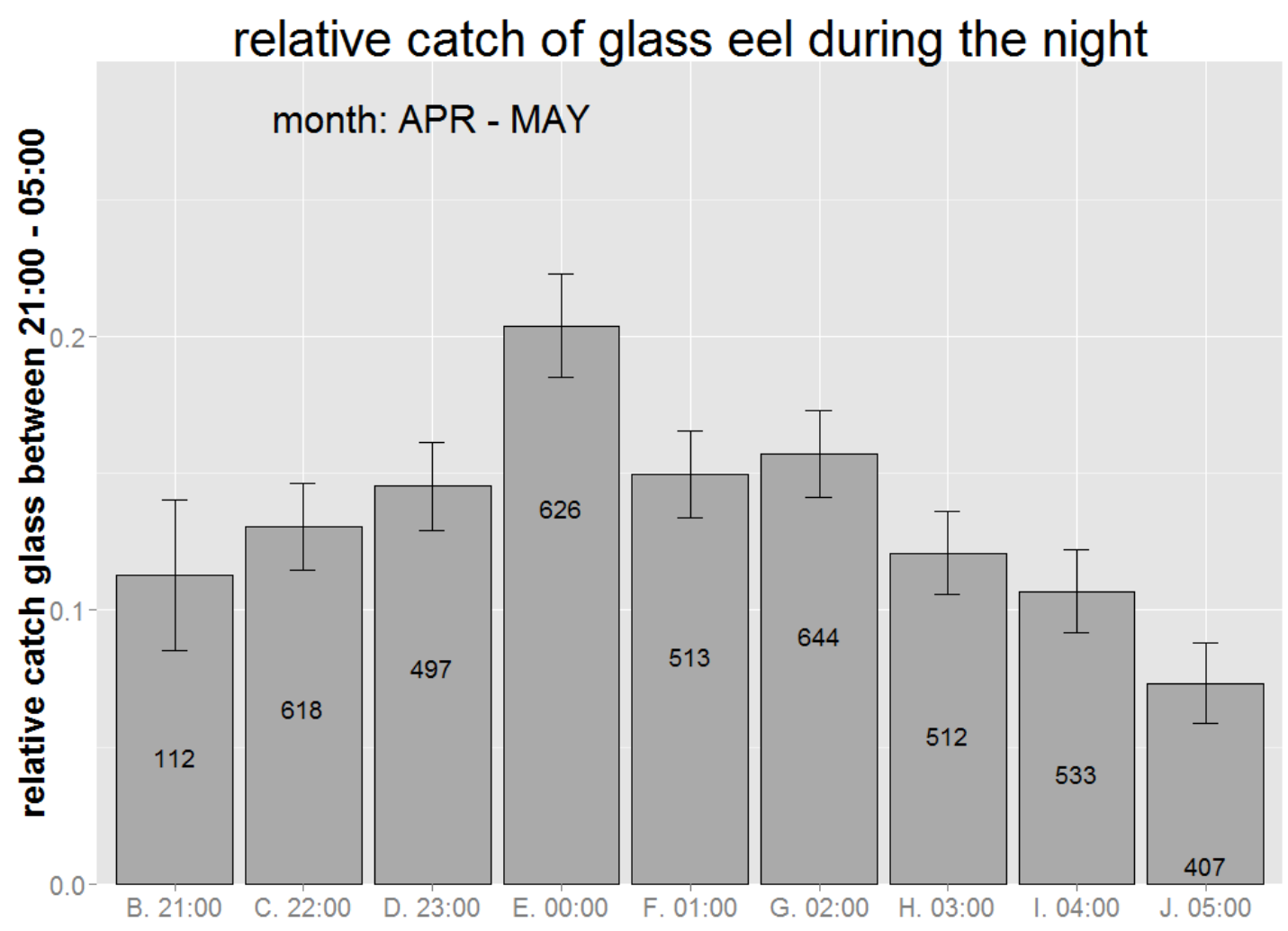

Figure 5-7 Average (relative) catches of glass eel during the night between 21:00 - 05:00. The graphs shows data of the months April and May.

\subsection{Conclusion}

There is a relation between glass eel abundance and tidal current with relatively more eel during high tide. Furthermore, catches are increasing with rising tide and, slowly, decreasing during ebbing tide. On average, during all tidal phases glass eel were caught. But, largest catches can be expected during high tide. When this type of monitoring is used for fish pass evaluation, management measure advice or simply as year to year index, it is important to take into account tidal cycles. An irregular planning of monitoring at tidal gates, in relation to tidal phases could cause biased conclusions. It would be better to take sufficient hauls during different phases of the tidal cycle, or correct for the tidal state during sampling with a statistical model. It is important to be consistent in timing of monitoring in relation to tidal cycles dependent on the number of hauls per night and per season, since catches differ during the tidal cycle. Compared to other studies and monitoring sites, Den Oever is the only one with consequent hauls during the night, during different tidal phases.

Whether there is a relation between discharge events and glass eel abundance is not taken into account within this study. The tidal gates can be opened during water levels when the Wadden Sea level is lower than the IJsselmeer level. Only then, flow direction towards the Wadden Sea is guaranteed. In other words, in the calculations, there is a possibility that, roughly taken, during phases 1-4 and 16-20 (Figure 5-3), glass eel are flushed out or flushed away. Or that sampling isn't possible during a discharge event. 


\section{Discussion: Monitoring glass eel at barriers using lift nets}

Liftnet monitoring is often used in monitoring programs of diadromous fish. However, quite often the data is misinterpreted as data showing freshwater immigration of glass eel. This is not correct and misleading. When using a liftnet, one measures the local density of glass eel in the vicinity of a barrier. It does not give (1) a quantitative number of glass eel in term of $\mathrm{kg} / \mathrm{ha}$ of the entire site and (2) an insight in the overall abundance of glass eel at a site throughout the season. To illustrate a misleading result: when an index value gives a value close to zero (very few glass eel) it is often interpreted as a bad year class or a less efficient monitoring location. However, a very low catch may mean that management measures are nearly $100 \%$ efficient in reducing local glass eel density as a result of efficient migratory passage (i.e. residence time of glass eel at the sampling location is very small, resulting in a flux of high numbers of glass eel passing but very low catches with the lift net). Therefore, if one wants to have information on quantitative numbers of glass eel, residents time, fish pass efficiency etc., we plead for an integrated approach combining lift nets with other additional methods (e.g. mark recapture in combination with additional traps) for data interpretation besides a 'simple' year to year index measurement to determine trends in abundance for a single location. And not to rely on lift net measurement alone, since those datasets will leave many questions as it comes to 'underlying' behavioural patterns. Liftnet monitoring is useful in producing an index value, assuming all conditions and monitoring activities are comparable to previous monitoring year(s). Other techniques are needed to give insight in a quantitative estimation of glass eel abundance or to give insight in overall abundance during a migration season at the site including spatial dynamics in abundance relating to tidal currents etc. .

Improving migratory opportunities (e.g. installing fish ladders, implementing management measures, adapted sluice regimes at the site or in the vicinity) negatively influences glass eel index monitoring. Moreover, timing of monitoring should also be taken into account. Glass eel activity is often limited to dark periods as reviewed by Winter et al. (2014). Changes at the monitoring site or changes in the vicinity of the monitoring site (e.g. other nearby barrier) may influence density, behaviour or migration success. Moreover, local and temporal conditions have a large effect on the glass eel catches and sampling with limited effort will not be able to detect significant parts of the time trends (Dekker 1986, 1998b, Dekker 2002a). Often the local conditions are extremely variable and many hauls under different conditions are needed to have reliable results. Dekker (1986) even mentions that locations with small sampling intensity are superfluous in terms of identification of very short term changes, and long term changes do not contradict the intensive Den Oever sampling series. As far as known, the glass eel monitoring series at Den Oever is the only series that takes into account several consecutive days during a longer period. Moreover, this series has multiple hauls during the night at different tidal levels in the same night.

It may be possible that catch data shows very low glass eel catches at a tidal barrier, but that freshwater barriers further upstream do show large catches of glass eel or vice versa. Many scenarios for underlying mechanisms that result in these density patterns are possible in explaining these differences in catch numbers. For example, the monitoring data of a tidal barrier in the Netherlands shows zero or very low local densities of glass eel for consecutive years (IJmuiden, sluice complex of the Noordzeekanaal), while there are relatively high catches of glass eel at freshwater pumping stations further upstream the channel. This may be a result of different barrier effects explained in Figure 6-1.

In consecutive barriers (from sea to polder), there may be an accumulative effect in glass eel migration and densities resulting in different catch patterns in time (Figure 6-1). The density of upstream pumping stations may directly be influenced by the accumulation of glass eel at tidal barriers and its ability to facilitate migration. Index monitoring data strongly depends on glass eel 
abundance, behaviour and abiotic circumstances. The complexity of a tidal barrier, migration opportunities and migration success are all driving factors in an index monitoring.

One should be really careful in data interpretation of glass eel monitoring data using (local) densities, without knowing other parameters such as residence time, new arrivals, tot abundance etc. Especially when comparing catches of different sites to each other.

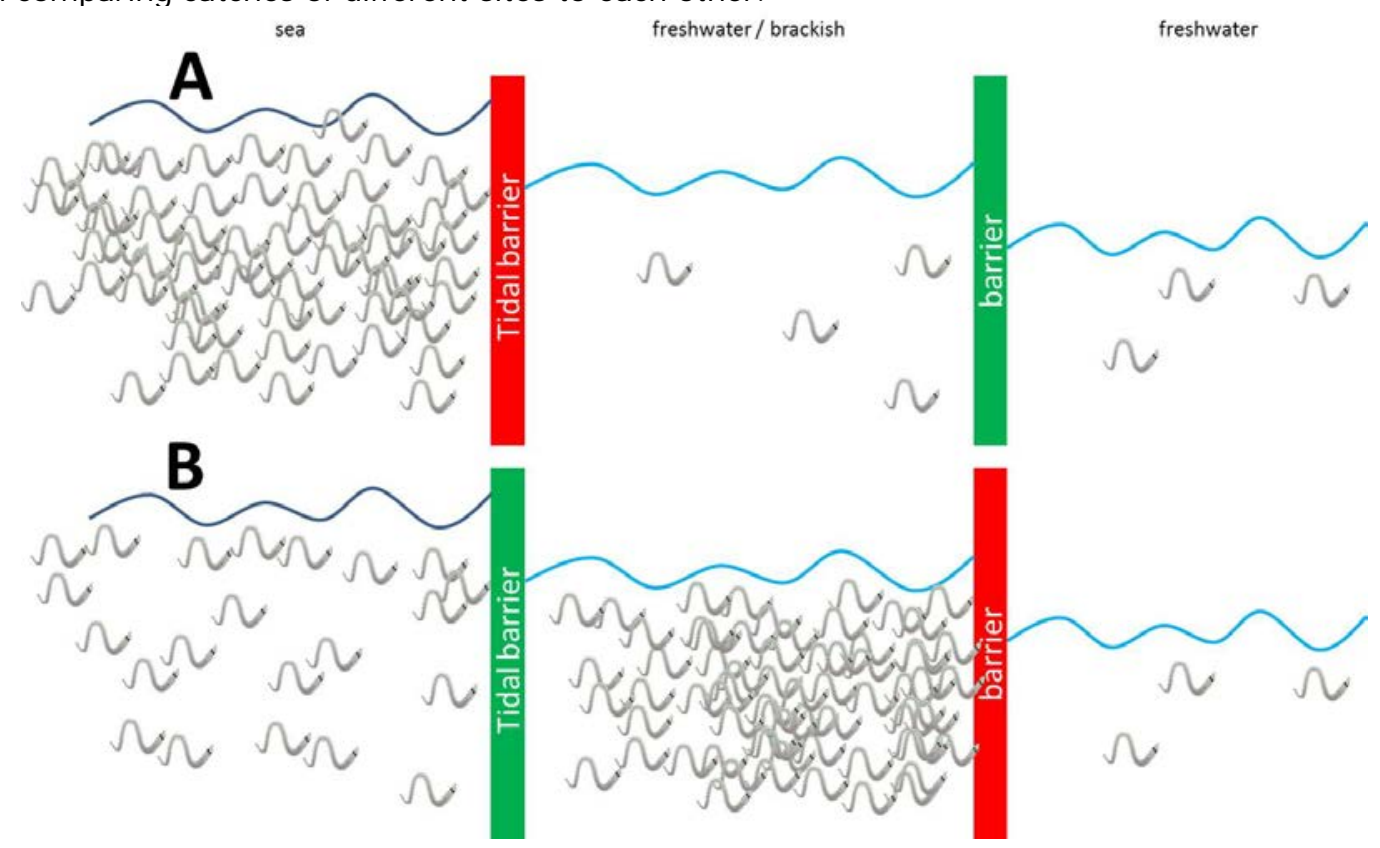

Figure 6-1 Hypothetical scenario of glass eel density at barriers in relation to the 'barrier effect'. Red barrier $=$ high barrier effect and thus high density of glass eel (during a longer period). Green barrier = low barrier effect and thus low densities of glass eel during the whole migration period. Scenario A and B both have the same absolute number of glass eel. However, different barrier effects result in different densities (index values). A - tidal barrier: index value high. A - freshwater barrier: index value low. B - tidal barrier: index value low. B - freshwater barrier: index value high.

Besides the barrier effect, local density of glass eel may vary in time. These variations may be the result of a different barrier effects in time, starvation, predation, alternative routes, etc. To visualize the possible scenarios in different index values, Figure 6-2, takes into account two consecutive barriers along a migration route from sea to inland waters. This may be a tidal barrier (e.g. sluice) and a freshwater barrier (e.g. pumping station). At all scenario's A-D, the same absolute number of glass eel arrives. In scenario $A$ and $B$, they all arrive within a short period, while at scenario $C$ and $D$, they arrive during a longer period. Barrier effects influences the density at the barrier and subsequent (second and third) barriers are highly influenced by the success of migration at the first barriers. Arrival at the second barrier may be later if the barrier effect is high at the first barrier ( $B$ and $D$ ). Also, arrival of glass eel may be more spread out during the migration period. These scenarios are taken into account in Figure 6-2A-D. These figures take notice of at least the following two factors:

1) Arrivals from the sea: Either this could be a short peak within the migration season of glass eel, or the abundance could be spread out during the whole season.

2) Barrier effect: When glass eel arrive at a barrier its success of passing the barrier depends on the barrier effect. When the barrier effect is high, migration rate will be low (e.g. long residence times and stronger aggregation effects in time) and vice versa.

Of course, the dimensions and the local hydrodynamics of the location / barrier are also of direct influence on the local density of glass eel. However, this varies between locations and is not taken into account. For example, discharge events or sluice activity can initiate a large reset of the spatial abundance of glass eel (i.e. frequently mixing and dispersing the glass eel over larger area alternated with concentration/aggregation more cosely to the bvarrier in between these 'reset' events). The more dynamic the hydraulic conditions in time and space are, the larger the chance of a partial or total reset of the spatial abundance of glass eel, resulting in higher fluctuations in catches within the lift net monitoring. 
Figure 6-2 A: The tidal barrier has a low 'barrier effect', i.e. offers good passage opportunities (Figure 6-2 A). Eel will pass quickly with low losses and short individual residence times in the vicinity of the barrier, resulting in a low density. Eel will then arrive at the freshwater barrier with limited delay. If the freshwater barrier has a low barrier effect, the eel will pass quickly with low losses. Resulting in a low density in front of the barrier. If the freshwater barrier has a high barrier effect, the eel cannot pass quickly and losses are higher (higher risk of predation and starvation). Resulting in a high density in front of the barrier during a relative long period.

Figure 6-2 B: The tidal barrier has a high 'barrier effect' (Figure 6-2 B). Eel cannot pass quickly and losses are inevitable (higher risk of predation and starvation). Eel arrive at the freshwater barrier with a (great) delay. Resulting in a high density in front of the barrier. If the freshwater barrier has a low barrier effect, the successful eel will pass quickly with low losses. Resulting in a low density in front of the barrier. If the freshwater barrier has a high barrier effect, the eel cannot pass quickly and losses are higher (higher risk of predation and starvation). Resulting in a high density in front of the barrier during a relative long period. Compared to scenario $A$, the losses at the tidal barrier will be higher resulting in a lower density of eel in front of the barrier under comparable circumstances.

Figure 6-2 C: The tidal barrier has a low 'barrier effect' (Figure 6-2 C). However, compared to scenario A, new arrivals will come during a longer period. This results in a lower density (index) compared to scenario $A$, which is rather constant in time. Eel will pass quickly with low losses. Eel arrive at the freshwater barrier with limited delay. If the freshwater barrier has a low barrier effect, the eel will pass quickly with low losses. Resulting in a low density (index) in front of the barrier. If the freshwater barrier has a high barrier effect, the eel cannot pass quickly and losses are higher (e.g. higher risk of predation). Resulting in a high density (high index) in front of the barrier during a relative long period.

Figure 6-2 D: The tidal barrier has a high 'barrier effect' (Figure 6-2 D). However, compared to scenario B, new arrivals will come during a longer period. Eel cannot pass quickly and losses are inevitable (higher risk of predation and starvation). The density of eel, will accumulate during the migration period. An index value will therefore be also divers throughout the whole migration period. Eel arrive at the freshwater barrier with a (great) delay. If the freshwater barrier has a low barrier effect, the successful eel will pass quickly with low losses. Resulting in a (more or less) constant low density (index) in front of the barrier throughout the whole period. If the freshwater barrier has a high barrier effect, the eel cannot pass quickly and losses are higher (higher risk of predation and starvation). Resulting in a high density (index) which may be divers throughout the period, in front of the barrier during a relative long period. Compared to scenario $B$, the losses at the tidal barrier will be higher resulting in a lower density of eel in front of the freshwater barrier under comparable circumstances.

The chance of catching an individual glass eel ('catchability') near tidal barriers could change dramatically when fish ladders, management measures or other factors change the local situation. Either the catchability improves due to a high barrier effect (high accumulation and long residence time) or is lowered due to improved migration opportunities (no accumulation and short residence time). Of course the impact of local changes to the catchability are related to the dimensions of the site and the behaviour of glass eel.

To identify changes in population size and year class strength, a factor of which is outside our direct sphere of influence, an index monitoring is introduced. An index monitoring measures the variation in year class strength and the yearly relative abundance of glass eel. Any change in the local situation, (e.g. fish pass, management measures, etc.) will make it very difficult to compare year to year variation of local abundance of glass eel between different periods ('break in the trend'). Many hauls per season are needed to have a reliable estimate of average density for a given year, which makes comparison between years possible as suggested by Dekker (Dekker 1986, 1998b, Dekker 2002a). 


\section{TIDAL BARRIER}
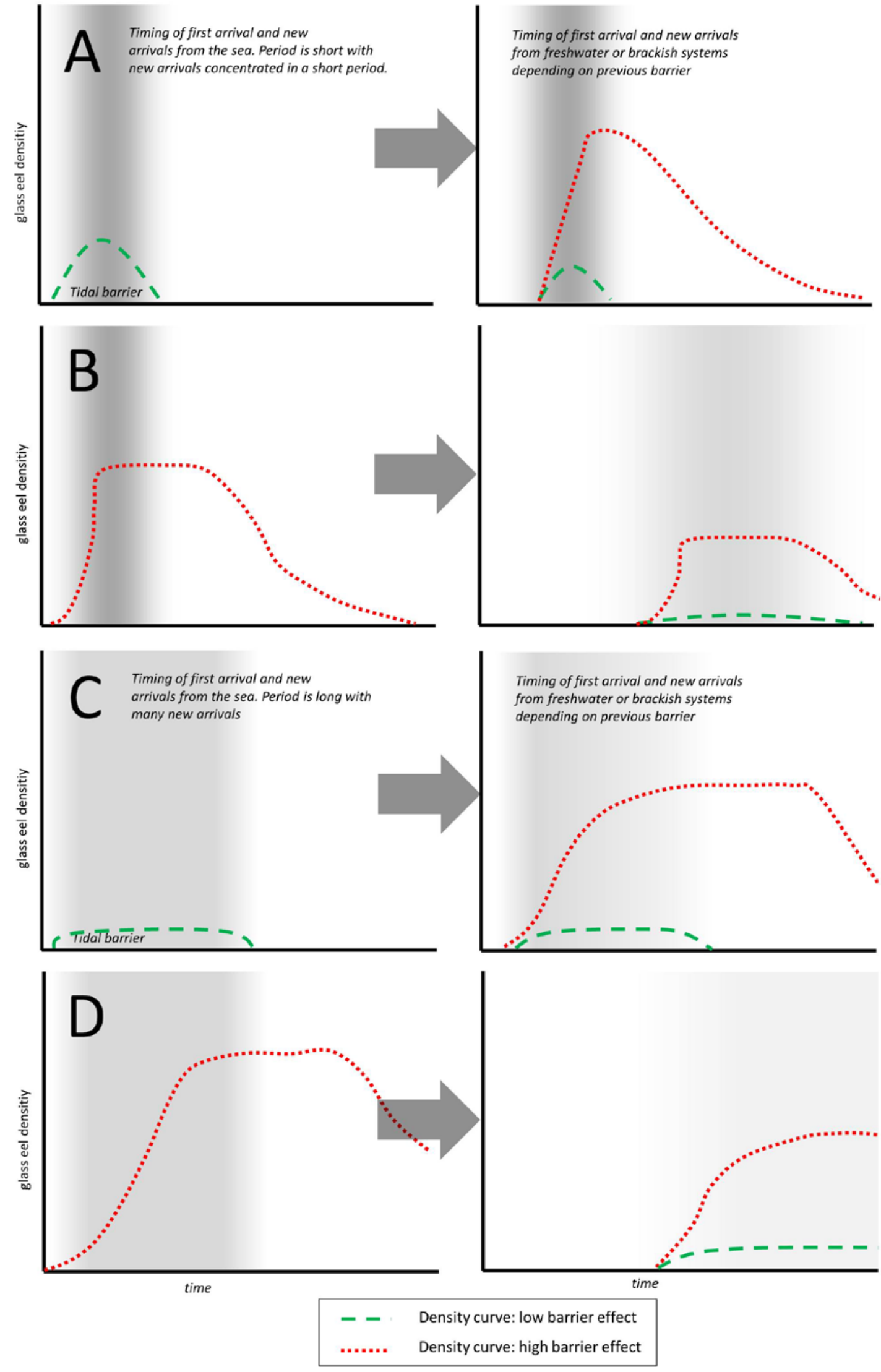

Figure 6-2 Scenario A-D. In these hypothetical scenario's, there are different factors taken into account such as: period of arrival and arrivals (grey areas) and barrier effect at consecutive barriers (e.g. tidal and freshwater barrier). Scenario A and B has a short glass eel arrival period. Scenario C and $D$ has a long glass eel arrival period with relatively more newly arrivals. 


\section{$7 \quad$ Conclusions and recommendations}

\section{Evaluation glass eel monitoring in the Netherlands and a National Glass eel I ndex}

In the Netherlands many glass eel monitoring programs have been executed throughout the years and many of them are still ongoing. However, most time series are relatively short and exposed to or will be exposed to changes in the local situation (e.g. resulting in changed migratory opportunities), causing difficulties for trend analysis. The monitoring program of Wageningen Marine Research is the only program with longer (e.g. >10 years) time series and therefore valuable for historic, year to year, comparison. By far the most thoroughly monitored location is Den Oever with several hauls per night throughout the tidal cycle, on consecutive days, throughout the migration period and since 1938. For this reason, the monitoring at Den Oever is used in the ICES advice on eel management and is internationally very valuable. A few other series are also used in the ICES advice: Katwijk, Lauwersoog, IJmuiden and Stellendam. They have, compared to Den Oever, only a small number of hauls per season. But, they have sufficient data for historic comparison.

The first exploration towards calculating one national glass eel index showed that it is highly influenced by the monitoring intensity at Den Oever, since the trend has been weighted by the number of hauls. Therefore, at this stage the national index is a 'noisy version' of the index graph of Den Oever. The other locations introduce noise in the index graph. For future purposes it is therefore recommended to intensify the number of hauls at the other locations. Preferably at locations along the Dutch coast and not within freshwater systems since the link to immigrating numbers from sea is less strong due to barriers more downstream from these locations. It is recommended that these locations should be divided in different regions; e.g. south, middle, north (comprising Den Oever), and northeast coast of the Netherlands. Or, in other words, equally divided along the Dutch coast as it is now, but the number of hauls should preferably be enlarged. Further statistical analysis must point out how many hauls are needed to have a sufficiently reliable estimate per region or location. However, it should be realized that many glass eel monitoring programs are executed by (many) volunteers. With the consequence that increased monitoring activities are not always possible.

In selecting locations it should also be taken into account that these barriers are 'stable' (e.g. no changes or management measures) in the future as well as barriers in the vicinity. When eel suddenly have better migration opportunities at nearby locations, this might also affect local density at the primary monitoring location. If this is the case, one can easily conclude that there is a bad year class, while in fact migration opportunities have been improved in such a way that a high(er) number of glass eel do not accumulate as compared to previous years. The conclusion may then be misleading. Therefore, if a fish pass is installed, it should be tested how it effects glass eel migration and changes in densities an residence times. In addition, sluice management should be tested and implemented in a similar manner. Since many locations have been altered throughout the years by management implications (e.g. fish passages) or will be altered in the future.

\section{Evaluation of monitoring using lift nets}

Lift nets are commonly used in the Netherlands. However, as written in this report, there are pros and cons in data interpretation of this method. Liftnet monitoring is often used in monitoring of small diadromous fish. However, quite often the data are misinterpreted as data showing overall numbers of immigrating glass eel. This is not correct. When using a liftnet, one measures the local density of glass eel in the vicinity of a barrier. It does not give (1) a quantitative number of glass eel in term of $\mathrm{kg} / \mathrm{ha}$ or total number at of the entire site and (2) a total insight in the overall abundance or density of glass eel at a site throughout the season.

Liftnet monitoring is useful in producing an year to year index value for a location, assuming all conditions and monitoring activities are comparable to previous monitoring year(s). Other techniques (e.g. mark recapture) are needed to give insight in a quantitative estimation of glass eel abundance or to give total insight in density at the site including spatial dynamics in abundance relating to tidal 
currents etc.. For this reason, Wageningen Marine Research has studied glass eel dynamics at Den Oever using an integrated approach of mark recapture techniques, additional lift net sampling on top of the existing monitoring and trawling (Foekema et al. in prep).

Glass eel occurrence, abundance, and density is highly influenced by 'barrier effect', migration opportunities and timing of arrival in time. Moreover, behaviour of glass eel in relation to tidal water levels should be taken into account. Preferably, glass eel monitoring is executed throughout the night at different water levels on consecutive days. When glass eel is monitored only once or twice a week, a peak could easily be missed and year to year comparison will be difficult or 'noisy'. Again, it should be realized that many glass eel monitoring programs are executed by (many) volunteers. With the consequence that increased monitoring activities are not always possible.

It is recommended to invest in 'stand-alone' methods that intensify monitoring effort with limited costs and flexible deployment. The use of light traps (Graaf et al. 2010) or artificial substrate samplers (pers. comm. R. Rosell, Agri Food and Bio Sciences Institute, UK) could be a solution, but should be further investigated.

\section{Relation tidal current and abundance of glass eel}

There is a relation between glass eel abundance and tidal current with relatively more eel during high tide at Den Oever. Furthermore, catches are increasing with rising tide and, slowly, decreasing during ebbing tide. On average, during all tidal phases glass eel were caught. But, largest catches can be expected during high tide. When this type of monitoring is used for fish pass evaluation, management measure advice or simply as year to year index, it is important to take tidal cycles into account. An irregular or infrequently planning of monitoring at tidal gates, in relation to tidal phases could result in biased conclusions. It would be better to take sufficient hauls during different phases of the tidal cycle, or correct for the tidal state during sampling with a statistical model. 


\section{Acknowledgements}

We would like to thank the many dedicated volunteers / fisherman of the Wageningen Marine Research glass eel monitoring program for fishing and counting the catch: A. de Boer, A. Kooij, A.A.M. Wagemaker, B. Schaub, C.J. Wagemaker, C.V. De Groot, D. Roon, D. van der Bent, D. van Stiphout, E. Poldervaart, E. van der Pal, E. Westerhuis, H. Gerrits, H. Ouwehand, H.J. Faber, I. Vink, I.E. Elema, J. Freijser, J. Heijligenberg, J. Rotgans, J.M.H. Schriever, J.T. Kay, K. Bouma, K. Hengst, K. Kesslerová, K. Mathot, L. van der Plas, M. Betgen, M. Reijmers, N. De Hilster, N. Dom, N. Minnen, N.M. Huisman, P. Caspers, P. Kooistra, R. Floor, S. Baars, S. De Groot, S.H. Kay, T. De Groot, W. Bruin, W. van der Bent, W. van der Gugten, W. van der Plas, W. van Nassau and (obviously) many others who volunteered during the previous years since the start of the monitoring (1938). Sometimes, many 'zero - catches' might be frustrating, especially during the dark and cold nights. We are therefore very grateful for all of your efforts throughout the years and looking forward to the coming years.

Further, we would like to thank Rijkswaterstaat for providing the water data. Furthermore RAVON and George Wintermans for their impressive monitoring activities in the Netherlands and providing information and data on their monitoring projects in the Netherlands. We're looking forward to further collaboration in future projects. 


\section{Quality Assurance}

Wageningen Marine Research utilises an ISO 9001: 2008 certified quality management system (certificate number: 187378-2015-AQ-NLD-RvA). This certificate is valid until 15 September 2018. The organisation has been certified since 27 February 2001. The certification was issued by DNV Certification B.V.

Furthermore, the chemical laboratory at IJ muiden has NEN-EN-ISO/IEC 17025:2005 accreditation for test laboratories with number L097. This accreditation is valid until $1^{\text {th }}$ of April 2017 and was first issued on 27 March 1997. Accreditation was granted by the Council for Accreditation. The chemical laboratory at IJ muiden has thus demonstrated its ability to provide valid results according a technically competent manner and to work according to the ISO 17025 standard. The scope (L097) of de accredited analytical methods can be found at the website of the Council for Accreditation (www.rva.nl).

On the basis of this accreditation, the quality characteristic $\mathrm{Q}$ is awarded to the results of those components which are incorporated in the scope, provided they comply with all quality requirements. The quality characteristic $\mathrm{Q}$ is stated in the tables with the results. If, the quality characteristic $\mathrm{Q}$ is not mentioned, the reason why is explained.

The quality of the test methods is ensured in various ways. The accuracy of the analysis is regularly assessed by participation in inter-laboratory performance studies including those organized by QUASIMEME. If no inter-laboratory study is available, a second-level control is performed. In addition, a first-level control is performed for each series of measurements.

In addition to the line controls the following general quality controls are carried out:

- Blank research.

- Recovery.

- Internal standard

- Injection standard.

- Sensitivity.

The above controls are described in Wageningen Marine Research working instruction ISW 2.10.2.105. If desired, information regarding the performance characteristics of the analytical methods is available at the chemical laboratory at IJ muiden.

If the quality cannot be guaranteed, appropriate measures are taken. 


\section{References}

Acou, A., P. Laffaille, A. Legault, and E. Feunteun. 2008. Migration pattern of silver eel (Anguilla anguilla, L.) in an obstructed river system. Ecology of Freshwater Fish 17:432-442.

Bergsma, J. H. 2015. Aanbod van aal op de Maas : monitoring van het aanbod (glas)aal vanaf de Maas bij gemalen Groenendaal, Gewande en Gansoijen. Bureau Waardenburg, Culemborg.

Calles, O., I. C. Olsson, C. Comoglio, P. S. Kemp, L. Blunden, M. Schmitz, and L. A. Greenberg. 2010. Sizedependent mortality of migratory silver eels at a hydropower plant, and implications for escapement to the sea. Freshwater Biology 55:2167-2180.

Creutzberg, F. 1958. USE OF TIDAL STREAMS BY MI GRATING ELVERS (ANGUI LLA-VULGARIS-TURT). Nature 181: 857-858.

Creutzberg, F. 1959. DISCRI MINATION BETWEEN EBB AND FLOOD TIDE IN MIGRATING ELVERS (ANGUI LLAVULGARIS TURT) BY MEANS OF OLFACTORY PERCEPTION. Nature 184: 1961-1962.

Creutzberg, F. 1961. On the orientation of migrating elvers (Anguilla vulgaris turt.) in a tidal area. Netherlands J ournal of Sea Research 1:257-338.

Dekker, W. 1986. Regional variation in glass eel catches: An evaluation of multiple sample sites Vie Milieu 36, 251-254.

Dekker, W. 1998a. Glasaal in Nederland - beheer en onderzoek. DLO-Rijksinstituut voor Visserijonderzoek, IJ muiden. RVIO-DLO rapport 98.002 .

Dekker, W. 1998b. Long-term trends in the glasseels immigrating at Den Oever, The Netherlands. Bulletin Francais De La Peche Et De La Pisciculture 349.

Dekker, W. 2004a. Slipping through our hands: population dynamics of the European Eel. . PhD thesis. University of Amsterdam.

Dekker, W. 2004b. What caused the decline of the Lake IJ sselmeer eel stock after 1960? Ices Journal of Marine Science 61:394-404.

Dekker, W., and J. vanWilligen. 1997. Hoeveel glasaal trekt het IJ ssemeer in? - verslag van een merkproef met glasaal te Den Oever in 1997 - RIVO rapport nr C062/97.

Dekker, W., and J. VanWilligen. 2000. De glasaal heeft het tij niet meer mee! - RIVO rapport nr C055/00.

Dekker, W. e. 2002a. Monitoring of glass eel recruitment - Volume 2A: Country Reports; Nothern part. Netherlands Institute for Fisheries Research.

Dekker, W. e. 2002b. Monitoring of glass eel recruitment - Volume 2B: Country Reports; Southern part. Netherlands Institute for Fisheries Research.

Dekker, W. e. 2002c. Monitoring of glass eel recruitment., Netherlands Institute of Fisheries Research.

Feunteun, E. 2002. Management and restoration of European eel population (Anguilla anguilla): An impossible bargain. Ecological Engineering 18:575-591.

Foekema, E. M., O. A. v. Keeken, and A. D. Rippen. 2014. Glasaalonderzoek Den Oever als onderdeel van het project Glasaal over de dijk. IMARES, Den Helder.

Foekema, E. M., M. J. J. Kotterman, P. d. Vries, and A. J. Murk. 2016. Maternally transferred dioxin-like compounds can affect the reproductive success of european eel. Environmental Toxicology and Chemistry 35:241-246.

Foekema, E. M., C. Sonneveld, and D. Burggraaf. 2015. Toepassing van videotechnieken bij monitoring glasaal. IMARES Wageningen UR, IJ muiden.

Ginneken, V. v., A. P. Palstra, M. Nieveen, J. H. J. v. d. Berg, G. Flik, F. A. Spanings, P. Niemantsverdriet, G. v. d. Thillart, and A. J. Murk. 2009. Effects of PCBs on the energy cost of migration and blood parameters of European silver eel (Anguilla anguilla). Pages 365-386 Spawning migration of the European Eel: Reproduction index, a useful tool for conservation management. Springer Netherlands.

Graaf, M. d., and C. M. Deerenberg. 2015. Report on the eel stock and fishery in the Netherlands 2013. IMARES, IJ muiden.

Graaf, M. d., J. W. v. d. Heul, J. A. v. Willigen, and T. B. Leijzer. 2010. The use of light traps in monitoring abundance of glass eel. I MARES, IJ muiden.

Griffioen, A. B., H. V. Winter, O. A. v. Keeken, C. Chen, E. v. Os-Koomen, S. Schoenlau, and T. Zawadowski. 2014. Verspreidingsdynamiek, gedrag en voorkomen van diadrome vis bij Kornwerderzand t.b.v. de VismigratieRivier. I MARES, IJ muiden.

Hop, J., and J. Kampen. 2012. Visintrek via inlaatwerk bij gemaal Colijn voorjaar 2012 : Waterschap Zuiderzeeland. ATKB Stellendam, Stellendam [etc.].

ICES. 2016. Report of the Joint EIFAAC/ICES/GFCM Working Group on Eel (WGEEL). 24 November-2 December 2015, Antalya, Turkey. ICES CM 2015/ACOM: 18. 130 pp. 
Jansen, H. M., H. V. Winter, M. C. M. Bruijs, and H. J. G. Polman. 2007. J ust go with the flow? Route selection and mortality during downstream migration of silver eels in relation to river discharge. Ices Journal of Marine Science 64: 1437-1443.

Kroes, M. J., H. Wanningen, P. v. Puijenbroek, and N. Breve. 2015. Nederland leeft met Vismigratie. Actualisatie landelijke database vismigratie., Sportvisserij Nederland, I MARES, Planbureau voor de leefomgeving.

Kroon, J. W., B. v. Wijk, and H. V. Winter. 2013. Onderzoek beschikbaarheid glasaal bij RWZI's t.b.v. herstel aalstand en uitzet binnenvisserij. Visserij Service Nederland, Groot-Ammers.

Kruitwagen, G., and M. Klinge. 2007a. Monitoring van stroomopwaartse migratie bij de gemalen Katwijk en Halfweg. Witteveen+Bos, Deventer.

Kruitwagen, G., and M. Klinge. 2007b. Visintrek bij de boezemgemalen Westland en Zaaijer. Witteveen+Bos, Deventer.

Kruitwagen, G., and M. Klinge. 2008. Monitoring van stroomopwaartse migratie van vis bij de gemalen Spaarndam en Gouda. Witteveen+Bos, Deventer.

Pedersen, M. I., N. Jepsen, K. Aarestrup, A. Koed, S. Pedersen, and F. Økland. 2012. Loss of European silver eel passing a hydropower station. Journal of Applied I chthyology 28: 189-193.

Projectgroep Samen voor de Aal. 2015. Samen voor de Aal; Kruisnetmonitoring Zuidwestelijke Delta 2015. stichting RAVON, Nijmegen.

Robinet, T. T., and E. E. Feunteun. 2002. Sublethal effects of exposure to chemical compounds: A cause for the decline in Atlantic eels? Ecotoxicology 11:265-277.

Ruijter, P. 2014. Intrek glasaal Gemaal Halfweg : bemonstering glasaalfuik voorjaar 2014. Visserijbedrijf Piet Ruijter, [Nederland].

Schaub, B., K. Kesslerová, G. van Wijk, L. van Dam, L. Vuister, F. den Dulk, M. Dijkstra, J. Arntz, M. Kroes, and R. de Boer. 2014. Visvriendelijk vijzelen : vispassage Halfweg helpt honderdduizenden vissen. Visionair : het vakblad van sportvisserij Nederland 8:20-23.

Schmidt, M. 1922. The breeding places of the eel. . Philosophical Transactions of the Royal Society BBiological Sciences 211: 179-208.

Sluis, M. T. v. d., H. M. J. v. Overzee, N. S. H. Tien, M. d. Graaf, A. B. Griffioen, O. A. v. Keeken, E. v. OsKoomen, A. D. Rippen, J. A. M. Wiegerinck, and K. E. v. d. Wolfshaar. 2014. Toestand vis en visserij in de zoete Rijkswateren. Deel II: Methoden. IMARES, IJ muiden.

Tesch, F. W. 1998. Age and growth rates of North Atlantic eel larvae (Anguilla spp.), based on published length data. Helgolander Meeresuntersuchungen 52:75-83.

van der Meer, J., H. W. van der Veer, and J. I. J. Witte. 2011. The disappearance of the European eel from the western Wadden Sea. J ournal of Sea Research 66:434-439.

van Heusden, G. 1943. De trek van den glasaal naar het IJ sselmeer. PhD - Thesis, Utrecht.

Werkgroep Monitoring Noordzeekanaal. 2014. Monitoring trekvissen in het Noordzeekanaal en Ommelanden met kruisnet door vrijwilligers. stichting RAVON, Nijmegen.

Winter, H. V., T. P. Bult, and J. A. v. Willigen. 2007a. Glasaalintrek in gebied Waterschap Zeeuwse Eilanden. I MARES, IJ muiden.

Winter, H. V., A. B. Griffioen, and O. A. v. Keeken. 2014. De Vismigratierivier: Bronnenonderzoek naar gedrag van vis rond zoet - zout overgangen. IMARES, IJ muiden.

Winter, H. V., A. B. Griffioen, and K. E. v. d. Wolfshaar. 2013. Inventarisatie van de belangrijkste knelpunten voor de uittrek van schieraal in Nederland. I MARES, IJ muiden.

Winter, H. V., and H. M. Jansen. 2006. De effecten van waterkracht en visserij tijdens de stroomafwaartse trek van schieraal in de Maas: zender-onderzoek gedurende 2002 - 2006. I MARES, IJ muiden.

Winter, H. V., H. M. Jansen, and A. Breukelaar. 2007b. Silver eel mortality during downstream migration in the River Meuse, from a population perspective. Ices J ournal of Marine Science 64: 1444-1449.

Winter, H. V., H. M. Jansen, and M. C. M. Bruijs. 2006. Assessing the impact of hydropower and fisheries on downstream migrating silver eel, Anguilla anguilla, by telemetry in the River Meuse. Ecology of Freshwater Fish 15:221-228.

Wintermans, G. J. M. 2015. Trekvisaanbod langs de waddenzeekust. Gegevensverslag voorjaar 2015; eindverslag 2012-2015. Wintermans Ecologenbureau (WEB).

Wintermans, G. J. M., and Z. Jager. 2003. Verslag visintrek waddenzeekust voorjaar 2003. Wintermans Ecologenbureau (WEB).

Wirth, T., and L. Bernatchez. 2003. Decline of North Atlantic eels: a fatal synergy? Proceedings of the Royal Society B-Biological Sciences 270:681-688.

Wolfshaar, K. E. v. d., N. S. H. Tien, A. B. Griffioen, H. V. Winter, and M. d. Graaf. 2015. Evaluation of the Dutch Eel Management Plan 2015: status of the eel population in the periods 2005 - 2007, 2008 2010 and 2011 - 2013. IMARES Wageningen UR, IJ muiden. 


\section{J ustification}

Report C010/17

Project Number: 4311218516

The scientific quality of this report has been peer reviewed by a colleague scientist and a member of the Management Team of Wageningen Marine Research

Approved: $\quad$ Dr. Ir. H.V. Winter

Senior researcher

Signature:

Date:

15 February

Approved:

Drs. J. Asjes

Manager Wageningen Marine Research

Signature:

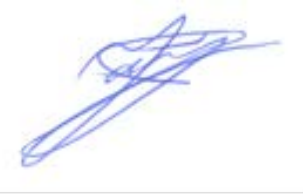

Date:

15 February 
Wageningen Marine Research

T +31 (0)317480900

E: marine-research@wur.nl

www.wur.eu/marine-research

Visitors' address

- Ankerpark 271781 AG Den Helder

- Korringaweg 5, 4401 NT Yerseke

- Haringkade 1, 1976 CP IJ muiden
Wageningen Marine Research is the Netherlands research institute established to provide the scientific support that is essential for developing policies and innovation in respect of the marine environment, fishery activities, aquaculture and the maritime sector.

\section{Wageningen University \& Research:}

is specialised in the domain of healthy food and living environment.

\section{The Wageningen Marine Research vision}

'To explore the potential of marine nature to improve the quality of life'

\section{The Wageningen Marine Research mission}

- To conduct research with the aim of acquiring knowledge and offering advice on the sustainable management and use of marine and coastal areas.

- Wageningen Marine Research is an independent, leading scientific research institute

Wageningen Marine Research is part of the international knowledge organisation Wageningen UR (University \& Research centre). Within Wageningen UR, nine specialised research institutes of the Stichting Wageningen Research Foundation have joined forces with Wageningen University to help answer the most important questions in the domain of 
